\title{
Union Membership Peaks in Midlife
}

David G. Blanchflower Alex Bryson

Quantitative Social Science Working Paper No. 20-06

August 2020 


\section{Disclaimer}

Any opinions expressed here are those of the author(s) and not those of the UCL Social Research Institute. Research published in this series may include views on policy, but the institute itself takes no institutional policy positions.

QSS Workings Papers often represent preliminary work and are circulated to encourage discussion. Citation of such a paper should account for its provisional character. A revised version may be available directly from the author.

Quantitative Social Science

UCL Social Research Institute

University College London

55-59 Gordon Square

London WC1H ONU 


\title{
Social Research Institute
}

\section{$\pm$

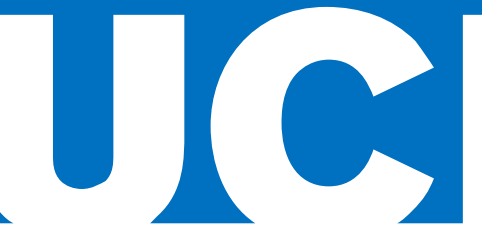

\section{Union Membership Peaks in Midlife}

\author{
David G. Blanchflower ${ }^{1}$ and Alex Bryson ${ }^{2}$
}

\section{$\underline{\text { Abstract }}$}

Using data from 68 countries on over 8 million respondents over forty years we show union membership peaks in midlife - usually around workers' late 40 s or early 50 s. In doing so we extend Blanchflower's (2007) earlier study, incorporating a further 39 countries and another decade or so of data. We also found it in every US state and the District of Columbia as well as across industries. The fact that this relationship exists in virtually every country across the world challenges a key precept in industrial relations, namely that institutions matter: they appear to matter little, at least in the case of the hump-shaped relationship between unionization and age. The union membership rates at the age peak in the United States and the United Kingdom have lowered over time, while the age at which the peak has occurred has increased in both countries. In part this is due to increasing union membership rates among those over the age of sixty-five. Declines in membership by birth cohort have lowered union density rates as the older cohorts with historically higher membership rates leave labour markets. Although we have yet to fully understand why union membership peaks in midlife we are able to examine some of the possible explanations. The findings have important implications for our understanding of trade unionism across the world.

Keywords: union membership; age; union density; cohort JEL Codes: J14; J50; J51

Acknowledgements: Alex Bryson would like to thank the Norwegian Research Council (grant no. 295914 /S20) for financial support. We thank Larry Kahn for helpful comments.

\footnotetext{
${ }^{1}$ Bruce V. Rauner Professor of Economics, Department of Economics, Dartmouth College, Division of Economics, Stirling Management School, University of Stirling, GLO, Bloomberg and NBER, Blanchflower@dartmouth.edu

2 Professor of Quantitative Social Science, Social Research Institute, University College London, NIESR and IZA, a.bryson@ucl.ac.uk
} 


\title{
1. Introduction
}

Although there has been a long-standing interest in the correlates of trade unionism among social scientists, the relationship between individuals' age and their propensity for union membership has attracted little attention. It was covered in a single sentence in Claus Schnabel's chapter on the correlates of union membership for the International Handbook on Trade Unions published in 2003. He stated:

\begin{abstract}
Research results on the relationship between age or, more appropriately, years of work experience and membership are somewhat mixed, with many estimated coefficients not being statistically significant, but in general this relationship tends to be positive or concave (increasing at a decreasing rate and possibly falling at the end).(Schnabel, 2003).
\end{abstract}

This changed in 2007 when Blanchflower (2007) showed union membership followed an inverted U-shaped - or hump shaped - pattern in age, peaking in midlife. Using micro-data files for 34 countries Blanchflower (2007) found that, prior to 2005, union density rates peaked in midlife maximizing in the mid to late $40 \mathrm{~s}^{3}{ }^{4}$ This U-shaped, or hump shaped, pattern was also found subsequently for Norway by Nergaard and Stokke (2007) and Posthuma (2009) in the World Values Survey, 1999-2002. Blanchflower found it made little difference whether controls were included, such as education, gender, race, occupation, location and so on; the probability of being a union member peaked in midlife.

Blanchflower (2007) offered ten, not necessarily mutually exclusive, reasons for the finding that union membership peaked in mid-life:

1. Cohort effects. Several experiments were conducted for the US and the UK to determine whether these results were driven by cohort effects. The evidence appeared to be to the contrary.

2. The inverted U-shape pattern in union membership reflects a broader life-cycle pattern

3. Union members quit their jobs from their late 40s and move to nonunion jobs in other organizations.

4. Union members lose their jobs and become unemployed

5. Union members quit their jobs and are promoted to managerial jobs in their own organization, or elsewhere, which are non-union.

6. Union workers are disproportionately employed in older workplaces, many of which are in traditional industries that have been subject to increased competition. When downsizing or plant closures occur, union members lose their jobs and are unable to replace them with comparable union jobs.

\footnotetext{
${ }^{3}$ The data used was the European Social Survey 1998-1994 and 2001; the Eurobarometers of 1988-1994 and 2001; the International Social Survey Programme 2000-2002; the UK Labour Force Surveys of 1993-2004; the General Household Survey of 1983; the MORG files of the CPS for 1984-2002 and the Canadian Labor Force Surveys of 1997-December 2005.

${ }^{4}$ The 34 countries were Australia*, Austria, Bangladesh*, Belgium, Bulgaria, Canada, Chile, Czech Republic, Denmark, Estonia*, Finland, France, Germany, Greece*, Hungary, Ireland, Israel, Japan, Italy, Luxembourg, Mexico*, the Netherlands, New Zealand, Norway, Poland, Portugal, Russia, the Slovak Republic, Slovenia, Spain, Sweden, Switzerland, the United Kingdom and the United States. The five marked as a * above were not founded here so the inverted U-shape has been found for a total of 73 countries.
} 
7. Older union workers increasingly free ride as they age. They enjoy union benefits but stop paying their union dues.

8. Older and younger workers have less 'need' for unions than prime-age workers.

9. The most productive union members quit because the seniority/wage compression rule reduces their potential earnings.

10. More highly unionized industries may have a higher proportion of older workers because the benefits brought by unions reduce turnover

His paper partially explores the first of these reasons - cohort effects - for the United States for the period 1983-2002 using 3.4 million workers from the Merged Outgoing Rotation Groups (MORG) files of the Current Population Survey (CPS). Cohort dummies for decade of birth were added as additional controls in a union membership equation, and collectively they were significant, showing that there are cohort effects in union membership. Decade of birth reduced the size of coefficients on the age variables that were included as five-year bands, plus they lowered the peak age. For example, in Blanchflower (2007) Table 8, column 3, with state dummies, the age maximum goes from 55-59 to the 35-39 category. Cohort effects were also found for the United Kingdom using the Labour Force Surveys (LFS) of 1992-2004. Once the cohort dummies are included the age paths are much flatter than without them.

The relationship occasioned little comment at the time from either the academic community or from employment relations practitioners. Although the paper has been Google cited 157 times subsequently, few of those papers focus on the relationship between age and trade union membership. Nevertheless, Jelle Visser - a leading authority on union density around the world even argued recently as follows.

Union density rates tend to increase with age in almost all countries. The issue here is that the differences between young and old have increased. The higher density rates of older workers are the result of higher density rates of past generations - in other words, of decisions made some thirty to forty years ago. Workers tend to join the union when they are young, most often when they have landed their first stable job and begun establishing a family (Visser, 2019).

We show in this paper that Visser is partially right - cohort effects do matter for union density. But we also show something that Visser does not comment upon, namely that union density peaks in midlife within cohort, and that this is true for all birth cohorts.

The age profile of union members is potentially important for trade unions keen to maintain their bargaining power and remain financially viable (Willman et al., 2020) - especially in a time of declining membership - and to the operation of the labour market - since unions tend to affect worker flows (notably quits), wages and wage growth, working conditions and, at plant and firm level, employment growth, productivity and profitability (Bennett and Kaufman, 2007). Even more broadly, the findings pose a challenge to a fundamental tenet of employment relations and labour economics generally, namely that institutions matter. If they do, then why was this humpshaped relationship between age and union membership apparent everywhere? 
Five issues remain outstanding following Blanchflower (2007): these are the motivation for this paper. First, the key finding was challenged, at least for one country (Germany) by Schnabel and Wagner (2012). They argued that the relationship disappeared with the addition of controls. We show this is not the case and that the disappearance of the raw correlation in their data occurs due to over-parameterisation. The problem arises when they incorporate cohort effects alongside age effects in estimates based on small samples. We should that the hump-shaped relationship between age and union membership is apparent for Germany, and that this is robust to the introduction of cohort dummies in Germany, as, indeed, is the case elsewhere. We go on to explain why the persistence of a hump-shaped age effect in the presence of cohort dummies is substantively important in understanding unionisation.

Second, Blanchflower's paper relies on data through to 2004, raising the question as to whether the association with age persisted after the Great Recession of 2008/9. It is conceivable that this huge economic shock resulted in differential job loss by age across the union and non-union sectors which may have affected the relationship. We tackle this issue by extending the analysis a decade or so after the Great Recession and find similar results.

Third, some countries not previously covered in Blanchflower (2007) may not exhibit a humpshaped association between age and union membership. We find U-shapes for 68 countries here and there were five in the Blanchflower (2007) paper in addition to those - Australia Bangladesh Estonia, Greece and Mexico- so to 61 countries over all - and find similar inverted U-shape patterns for all of them.

Fourth, the literature on the decline in union membership, apparent in many parts of the world, has tended to focus on younger workers' attachment to unionisation. Analysts suggest that the failure of younger workers to join unions has played an important part in declining union density, in part because falling membership has a snowball effect by reducing the likelihood of new entrants to the labour market experiencing the value of union membership, resulting in a rise in "nevermembership" which has been observed in the UK (Bryson and Gomez, 2005) and the United States (Booth et al., 2010). Thus, although inter-generational transmission of unionisation is still apparent (Bryson and Davies, 2019) young workers are less likely to join unions because their parents were less likely to be members than their parents. There has been speculation that there has been a shift away from collectivist values that underpin the provision of public goods through union solidarity towards individualist values which reduce young workers' perceived value of joining a union ${ }^{5}$ although the evidence - at least for English-speaking economies - appears to run counter to this argument (Bryson et al., 2005; Waddington and Kerr, 2008).

In any event, both these lines of argument (the snowball effect and changes in demand for unionisation) are essentially about cohort effects - the propensity of later-born generations to join unions compared to earlier generations - rather than age effects. We show that the hump-shaped age effect is apparent when one controls for cohort effects, so this is not what lies behind the humpshape. However, we go further by examining these age effects across time. We show that in the two countries for which we have the longest time-series - the United States and the United Kingdom - union membership rates decline in later cohorts, thus contributing to declining union

\footnotetext{
${ }^{5}$ For a discussion of the shift to a more consumer-oriented culture and its implications for the 'taste' for trade unionism see Bryson et al. (2010a).
} 
density over time, but the hump-shape in age persists in each cohort. The union membership rate at the age peak in the United States and the United Kingdom has lowered over time, while the age at which the peak has occurred has increased in both countries. In part this is due to increasing union membership rates among those over the age of sixty-five. The peak gradually creeps upwards - in the United States from age 46 to age 49 between 1983 and 2018, and in the United Kingdom from age 46 in 1992 to age 53 in 2019.

Finally, although Blanchflower (2007) enumerates possible reasons as to why union membership peaks in midlife he only briefly speculates about possible answers to the question. He suggests that the likely reason for the midlife peak in union membership was the fact that older union workers are paid above the values of their marginal products; employers thus have incentives to replace them. The mechanisms by which this is done, he thought, would likely vary across countries. In this paper we tackle some of those reasons. But some avenues for further exploration remain open. We return to this issue in the final section of the paper.

In the next section we present our empirical results showing that union membership peaks in midlife across the world. We begin with the United States, followed by the United Kingdom, before turning to Europe - where we spend some time focusing on Germany given Schnabel and Wagner's (2012) earlier paper - before going on to the rest of the world. Finally, in this section we turn to the changing age distribution of union membership in the two countries where we have a long timeframe, namely the United States and the United Kingdom. In our concluding section we discuss the implications of our findings and address some of the reasons as to why we find union membership peaking in middle-age.

\section{Empirical Results}

In this section we present estimates of a peak in midlife of union membership probabilities in sixtyeight individual countries using data on just over 8 million respondents, maximizing around age fifty. ${ }^{6}$ We examine several of the same data files examined by Blanchflower (2007) and extend them all to the present, including the MORG files for the United States (1983-2018) and the Labour Force Survey (LFS) files for the United Kingdom (1992-2019) and the European Social Surveys (2002-2018). We also examine the World Values Surveys (1981-2019); all four of these surveys allow us to examine the role of cohort effects in a subset of countries. In addition, we examine cross-section data from the 2015 International Social Survey Programme (ISSP) and Gallup World Poll data for Asia and the South Pacific (2010-2013). It turns out that the inclusion of cohort dummies has little impact on the age peak and neither does the addition of additional personal controls such as education and labor force status measures such as measures of self-employment or underemployment (part-time wants full-time). In every case we restrict our samples to workers only.

6 We find an inverted U-shape with cohort dummies for fifty countries - Andorra; Austria; Azerbaijan; Belarus; Belgium; Bolivia; Bulgaria; Canada; Chile; China; Cyprus; Czech Republic; Denmark; Ecuador; Finland; France; Germany; Hungary; Iceland; India; Ireland; Israel; Italy; Japan; Kyrgyzstan; Lebanon; Luxembourg; Malaysia; Montenegro; Netherlands; Nigeria; Norway; Poland; Portugal; Romania; Russia; Singapore; Slovakia; Slovenia; South Africa; Spain; Sweden; Switzerland; Taiwan; Tanzania; Turkey; Ukraine; United Kingdom; USA and Vietnam. We find it for eighteen others without cohort controls: Armenia; Bosnia; Brazil; Cambodia; Croatia; Georgia; Hong Kong; Macau SA; Mali; Nepal; New Zealand: Palestine; Rwanda; South Korea; Suriname; Tunisia; Uruguay; and Yugoslavia. 


\subsection{United States}

The Bureau of Labor statistics reports annually on the characteristics of union members. In 2019 $10.3 \%$ of workers were members of unions. ${ }^{7}$ Membership rates varied by age as follows:

$\begin{array}{lrrrrr} & 2000 & 2008 & 2010 & 2015 & 2019 \\ \text { All } & 13.4 & 12.4 & 11.9 & 11.1 & 10.3 \\ 16 \text { to } 24 & 5.1 & 5.0 & 4.3 & 4.4 & 4.4 \\ 25 \text { to } 34 & 11.7 & 10.7 & 10.1 & 9.7 & 8.8 \\ 35 \text { to } 44 & 14.6 & 13.4 & 12.8 & 12.3 & 11.8 \\ 45 \text { to } 54 & 18.8 & 16.0 & 15.0 & 13.6 & 12.6 \\ 55 \text { to } 64 & 17.6 & 16.6 & 15.7 & 14.3 & 12.7 \\ 65+ & 8.1 & 9.0 & 10.0 & 9.5 & 9.7\end{array}$

Membership rates have declined since 2000 for all groups except for those ages sixty-five and over. There is an obvious turn in age in these raw data with rates rising after midlife, in the agerange 45-54 in 2000 and in the range 55-64 since then, and then a decline in rates for the oldest group of workers. Of note is the fact that, in contrast to all other age groups, the membership rate for the $65+$ is higher in 2019 , by nearly two percentage points, than it was in 2000 .

In Table 1 we examine this hump-shaped unionization rate in age for the United States in a little more detail with three micro-datasets. The first three columns use the Merged Outgoing Rotation Group files of the Current Population Survey from 1983-2018 provided by the NBER. ${ }^{8}$ In column 1, with 6.2 million observations, with controls for gender, race, state, year and month of interview (and a private sector dummy in column 1), age is negative and age squared is positive, both with t-statistics of around 200, implying an inverted U-shape. We differentiate with respect to age and solve and calculate an age maximum of 48. Column 2 adds decade of birth cohort dummies which are statistically significant but have little impact on the age variables. Blanchflower (2007: Table 5) used the same MORG files and found a maximum of 48 for 1984-1991 and 49 for 1992-2002. ${ }^{9}$ Columns 3 and 4 for the public and private sectors are similar, with cohort dummies, with maxima of 48 and 45 respectively.

Column 5 uses the Gallup United States Daily Tracker Poll (GUSDTP) ${ }^{10}$ for 2008-2017 with 1.4 million observations with the same controls including cohort - and shows the same with a maximum of 47 also. The final column 6 uses the much smaller General Social Survey ${ }^{11}$ that has a longer time run back to 1973 with the same controls and essentially identical results.

The quadratic age term imposes a functional form on the association with age so in Chart 1 we simply rerun column 2 for the MORGs and column 5 for GUDSTP replacing the two age terms with a full set of year-specific age dummies. We do this rather than plot the raw means so we can

\footnotetext{
${ }^{7}$ Union members, 2019, BLS. https://www.bls.gov/news.release/pdf/union2.pdf and https://www.bls.gov/webapps/legacy/cpslutab1.htm

${ }^{8}$ https://data.nber.org/morg/annual/

${ }^{9}$ Blanchflower (2007) included controls for industry as well as for education. They have little impact here so for simplicity and to be comparable across data files we just use parsimonious specifications.

${ }^{10} \mathrm{https} / / / \mathrm{www} . \mathrm{gallup} . \mathrm{com} / 174155 /$ gallup-daily-tracking-methodology.aspx

11 https://gss.norc.org/get-the-data
} 
take out the time and area effects. We take the coefficients from this regression, add the constant, and plot the numbers. The two scatter plots have clear and similar hump shapes with maxima around age fifty, confirming the quadratic specifications, albeit with a flat tail after around age 70.

In Table 2 we explore whether this pattern holds within states of the United States. We classify states according to whether they have passed Right-to-Work (RTW) laws which prohibit union security agreements between employers and labor unions. Under these laws, employees in unionized workplaces are banned from negotiating contracts which require all members who benefit from the union contract to contribute to the costs of union representation. The institutional settings in these two sets of states are very different with RTW states being more hostile to union organizing than non-RTW states. Over the period in question seven states implemented RTW laws - Idaho; Indiana; Kentucky; Michigan; Oklahoma; West Virginia and Wisconsin. In every case there is a peak in union membership in midlife and a peak is present for these seven states before and after the switch. The peak in RTW states was 47 and 48 in non-RTW states. The minimum was 42 in Georgia, an RTW state and the maximum was in Vermont, at 54, a non RTW state. Institutions seem to have little impact on the age peaks in union membership.

We also find the same hump-shaped age profile for union membership within industrial sectors in the United States, and it exhibits similar variance to that across states, with the membership peaking at 42 years in Public Administration compared with 57 years in Professional services.

\subsection{The United Kingdom}

In the United Kingdom the Office of National Statistics provides data on union membership. ${ }^{12}$ As in the United States, union density rates have been gradually declining for some decades (although it has actually risen in the last three years (ONS, 2019). As can be seen below membership rates among employees have fallen for every age range over time, except among those aged 60-64, where they have been stable, and those aged 65+, where they have risen. Membership rates peak in midlife but just as in the United States the peak has moved upwards from age 45-49 in 2000; to 50-54 in 2008, 2010 and 2015 to 55 to 59 in the latest release. We return to this issue in Section 2.6.

$\begin{array}{lccrrr} & 2000 & 2008 & 2010 & 2015 & 2019 \\ \text { All Employees } & 29.8 & 27.5 & 26.6 & 24.7 & 23.5 \\ 16 \text { to } 19 & 5.4 & 4.4 & 3.9 & 2.4 & 3.3 \\ 20 \text { to } 24 & 14.3 & 12.1 & 12.1 & 11.6 & 10.4 \\ 25 \text { to } 29 & 23.1 & 20.2 & 19.5 & 17.7 & 18.5 \\ 30 \text { to } 34 & 28.2 & 24.9 & 22.6 & 21.9 & 21.0 \\ 35 \text { to } 39 & 33.5 & 27.5 & 27.0 & 25.2 & 23.3 \\ 40 \text { to } 44 & 37.2 & 33.3 & 31.2 & 26.1 & 25.3 \\ 45 \text { to } 49 & 40.3 & 35.4 & 34.1 & 30.3 & 28.5 \\ 50 \text { to } 54 & 38.5 & 38.4 & 37.6 & 36.0 & 31.1 \\ 55 \text { to } 59 & 36.7 & 38.2 & 37.1 & 34.0 & 32.5 \\ 60 \text { to } 64 & 30.7 & 29.0 & 28.2 & 30.0 & 30.0\end{array}$

\footnotetext{
${ }^{12}$ Data are available three of the twelve monthly surveys each year: in September, October and November for 19922005 and in October to December 2005-2019. In four years, 2011, 2012, 2016 and 2017 there are a few cases for January. https://data.gov.uk/dataset/2139dde9-cb3a-43c3-9c93-dc98b91d448e/trade-union-membership
} 
As in the United States, in contrast to the younger age groups, the membership rate of those age 65-69 is higher in 2019 than it was in 2000. We only have data for those 70 and over since 2007 but rates have risen sharply over the past decade.

Blanchflower (2007) also examined data on union membership using the UK Labour Force Surveys of 1993-2004 and found union probabilities maximized at age 48. Table 3 makes use of the same LFS data but now from 1992-2019 and the specifications are equivalent to those above for the United States. The inverted-U shape is apparent in all five estimates presented. In column 1 for the whole economy and in the absence of cohort controls union membership reaches a peak in midlife at age 49. The inclusion of cohort dummies in column 2 makes barely any difference, with membership now peaking at age 50. There are inverted U-shapes also in the private and public sectors (columns 3 and 4 respectively). The hump or hill-shape is also apparent in each of the nine English regions as well as Wales, Scotland and Northern Ireland, with the highest in London at age 56, with the others close to age fifty. Chart 2 plots the raw data for the UK showing an inverted U-shape rather than the single year of age plots from a regression to make it clear that there is a big drop in membership rates at age 65 .

\subsection{Europe}

Table 4 now moves to examine European Social Survey (ESS) data ${ }^{13}$ for $2002-2018$ for the EU28 plus ten other European countries extending the 2002 and 2004 data used by Blanchflower (2007) so sample sizes are now large enough with a long run of years that it is possible to include decade of birth cohort dummies. There is an inverted U-shape in age in column 1 without sweep, country or cohort dummies and an age maximum of 58. Including country and survey sweep dummies lowers the age maximum to 55 in column 2 and adding cohort variables in column 3 lowers it further to age 54. The maxima are a little higher than for the United Kingdom and United States in the previous tables. Column 4 reports the results for Germany and finds an inverted U-shape with a maximum at age 54, with cohort dummies, a finding we return to in Section 2.4 below. The table also reports maxima for twenty-eight of the thirty-eight countries in the sample with the full set of controls included in columns 3 and 4. We found membership was an inverted U-shape in age for all the major European countries. ${ }^{14}$ Chart 3 shows an inverted U-shape for Europe, plotting the single year of age coefficients using the column 3 specification. The chart shows a humpshape in age in union membership probabilities comparable to those found in the previous two charts for the United States and the United Kingdom.

We thus now have a running total of U-shapes in 29 countries with cohort controls - Austria; Belgium; Bulgaria; Cyprus; Czech Republic; Denmark; Finland; France; Germany; Hungary;

\footnotetext{
13 The countries are Albania; Austria; Belgium; Bulgaria; Croatia; Cyprus; Czechia; Denmark; Estonia; Finland; France; Germany; Greece; Hungary; Iceland; Ireland; Israel; Italy; Kosovo; Latvia; Lithuania; Luxembourg; Montenegro; Netherlands; Norway; Poland; Portugal; Romania; Russian Federation; Serbia; Slovakia; Slovenia; Spain; Sweden; Switzerland; Turkey; Ukraine; United Kingdom; see https://www.europeansocialsurvey.org/data/ ${ }^{14}$ We didn't find the inverted U-shape for Albania; Croatia; Estonia; Greece; Kosovo; Latvia; Lithuania; Montenegro; Serbia; or Turkey.
} 
Iceland; Ireland; Israel; Italy; Luxembourg; Netherlands; Norway; Poland; Portugal; Romania; Russia; Slovakia; Slovenia; Spain; Sweden; Switzerland; UK; Ukraine and the USA.

\subsection{Germany}

Schnabel and Wagner (2012) argued that in the case of West Germany there was no inverted Ushape in age. In contrast, Blanchflower (2007) found inverted U-shapes for West Germany using the International Social Survey Programme (ISSP) and Eurobarometer files with age maxima of 43 in both cases. Schnabel and Wagner (2012) used ALLBUS data for three time periods; 19801988; 1990-1998 and 2000-2006. They did not report a pooled estimate for all years, despite small sample sizes which caused major problems as we note below. ${ }^{15}$ First, in all of the six cases in the raw data, which they called their Model 1, there was an inverted U-shape - that is the age coefficient was positive and the age squared negative and both were significant. If we look at the specification using their Model 1 and solve the probabilities membership for men maximizes at ages 51, 49 and 51 and for women 39, 45 and 46 for the 1980s, 1990s and 2000s respectively.

The significance of these two age terms disappeared in their Model 2 with the inclusion of cohort dummies. Unfortunately, there are not enough degrees of freedom to do so given the high correlation between the age and cohort variables with such small sample sizes. Their Model 3 adds year dummies and their Model 4 adds personal controls, but they are not informative due to the inappropriate inclusion of the cohort variables. As an illustration, below we present their results for 2000-2006 for men, with a sample size of 1950 only, using Model 1 with just the age variables and then Model 2 adding eight cohort dummies for 1916-1925, 1926-1935, 1936-1945, 1946-1955, 1956-1965, 1966-1975, and 1976-1985 identifying year of birth, that are illustrative, just for men. The coefficients and p-values are reported. Both age variables are highly significant in Model 1. The addition of the cohort dummies destroys the significance of the two age terms which go from highly significant to highly insignificant.

$\begin{array}{lll} & \text { Model 1 } & \text { Model 2 } \\ \text { Age } & .0639 & .00042 \\ \text { p-value } & .003 & .993 \\ \text { Age squared } & -.00067 & -.00012 \\ \text { p-value } & .016 & .819 \\ \text { Age maximum } & 51 & \\ \mathrm{~N} & 1950 & 1950\end{array}$

It should be noted that including age and age squared to model any potential U-shapes in age in union membership equations is simply a convenient shorthand. Schnabel and Wagner (2012) apply procedures suggested for testing U-shapes especially when they are impacted by outliers. The authors of that test Lind and Mehlum (2010) argued as follows

"Most works, nevertheless, seem to be on fairly safe ground when they claim to have found a $U$ shape. The reason is that the de facto common practice seems to be to check two necessary conditions, namely that the second derivative has the right sign and that the extremum point is within the data range. However, only the results

15 Men 1980-1998=2943 (1767); 1990-1998=2907 (1950); 2000-2006=1708 (1309) with female numbers in parentheses. 
from the former are usually reported. This criterion will be misleading, however, if the estimated extremum point is too close to the end point of the data range."

Using a flexible functional form overcomes any difficulties in relation to turns in the data especially in the upper tail. Restricting the cut off age solves most of the problems but, in general, these seem to be small sample problems.

Chart 4 takes the data from the European Social Survey for Germany and plots the single year of age coefficients, added to the constant. This allows us to determine if there are any outliers and whether the quadratic form is appropriate. An issue of course could be that there are turns in the data especially after retirement age. This usually can be solved easily by restricting the sample to prime age workers from say, 16 to 70 . We also fit the quadratic from Table 4 column 4 and alongside that also fit a quadratic to the year of age plots (which takes the form -.1408Constant + $.0097 \mathrm{Age}-.0009 \mathrm{Age}^{2}$ ) which maximizes at age fifty-four.

In the final column of Table 4 the function also reached a maximum at age 54. Using both methods there is a clear inverted U-shape maximizing at the same age. Contrary to the claims of Schnabel and Wagner (2009) there are U-shapes in Germany even when cohort effects are controlled for in our data. This is hardly surprising: the inverted-U shape in age has been found previously for West Germany in panel random effects models using the German Socio-economic Panel Survey for 1985-1998 by Beck and Fitzenberger (2004: Table 4).

\subsection{The World}

So far, our analyses have been confined to the United States and European countries. But we have data for other parts of the world too. Table 5 uses data from a pooled sample of seven sweeps of the World Values Survey (WVS) with 200,000 observations to estimate union membership equations across 101 countries. ${ }^{16}$ In column 1 with only the age and gender variables there is another inverted U-shape for union membership by age with a maximum at age forty-five. Adding wave and country dummies, as well as contractual status, in column 2 increased the age maximum to age 47 and adding the cohort dummies in column 3 raises the maximum to age 49 . Chart 5 plots the single year of age coefficients using the specification in column 3 with cohort dummies and the hump shape is apparent again. We fitted a quadratic to the single year of age plots (which takes form -.1065 Constant $+.009 \mathrm{Age}-.00009 \mathrm{Age}^{2}$ ) which maximizes at age 50 .

Table 5 also reports results for thirty-two countries including some advanced countries - Canada, Japan, Sweden and the USA but also several developing countries including China (where membership has been rising), India, Azerbaijan, Kyrgyzstan, Malaysia, Nigeria, Taiwan, Tanzania and Vietnam. We report results for countries for whom both the age and age squared coefficients respectively were positive and negative with both having t-statistics of $>1.65$ with models including cohort dummies. The overall midpoint is age 45 which is also the mean of the country level estimates. This adds another 21 countries to the list taking the total to 50 - Andorra; Azerbaijan; Belarus; Bolivia; Canada; Chile; China; Ecuador; India; Japan; Kyrgyzstan; Lebanon; Malaysia; Montenegro; Nigeria; Singapore; South Africa; Taiwan; Tanzania; Turkey and Vietnam.

${ }^{16}$ The WVS sweeps are 1981-1984 (6,081); 1989-1993 (10,294); 1994-1998 (39,543); 1999-2004 (20,285); 2005 2009 (40,794); 2010-2014 (45,208) and 2017-2019 (40,771) and all $(202,976)$ with \# observations in parentheses. 
Many of these countries had few observations and often only a single wave of data so we reran the estimation excluding the cohort variables and found U-shapes for a further eighteen countries Armenia; Bosnia; Brazil; Bulgaria; Croatia; Finland; Hong Kong; Italy; Macau SA; Mali; New Zealand; Norway; Palestine; Rwanda; South Korea; Tunisia; Uruguay; Yugoslavia. Of these thirteen were new - Armenia; Bosnia; Brazil; Croatia; Hong Kong; Macau SA; Mali; Palestine; Rwanda; South Korea; Tunisia; Uruguay; and Yugoslavia. This takes the total to 63 countries.

We now move to a cross-section data file, the 2015 International Social Survey Programme (ISSP) on 37 countries with just under 27,000 observations. Table 6 reports once again there are inverted U-shapes in age for union membership which maximize around age 50 once country dummies are added. We re-estimated by country using the specification in column 2 and found significant Ushapes - with t-statistics on the age and age squared variable both $>1.65$. The fact that we don't have enough time series variation to include cohort effects is unlikely to be a major problem given we have shown how small an effect their inclusion has in Tables 1-5 above. The sample sizes are small, mostly with under 1000 observations, but we still found U-shapes in fifteen countries, including in two new countries - Suriname and Georgia with cohort dummies. Now we have 65 countries.

\subsection{South Asia and South Pacific}

In Table 7 we report union membership equations using the Gallup World Poll for 2010, 2012 and 2013 on 21 developing countries- Afghanistan; Bangladesh; Bhutan; Cambodia; China; Hong Kong; India; Indonesia; Laos; Malaysia; Mongolia; Myanmar; Nepal; Pakistan; Philippines; Singapore; South Korea; Sri Lanka; Taiwan; Thailand; Vietnam; plus the three main developed countries from the region - Australia, Japan and New Zealand. There are U-shapes in age once more with a maximum at age 55 in column 3.

We find significant U-shapes in nine countries including in three new ones - Cambodia, Nepal, and New Zealand taking us to 68 countries in total.

\subsection{Changes in Union Membership by Age Peak Over Time - the United States and the United Kingdom}

We have established that the age-profile of union membership is hump-shaped across the world, but has this hump-shape changed over time? It turns out that, whilst membership rates have fallen across the age distribution, the hump-shape remains but the peak in age has increased over time. To investigate this question, we examine data for the two countries for which we have the largest data sets stretching back a long time, namely the United States and the United Kingdom. The data from the MORG files from 1983-2018 in the United States and the Labour Force Survey from 1992-2018 are well suited for this purpose. We simply take the weighted means in our date files, and to ensure large sample sizes we pool several years of data together.

In Chart 6 we do this exercise for five-year groupings - from the start of the series in 1983 through 2018 - for the United States. We see a flattening of the top of the distribution over time - akin to a mountain seeing its peak flattened. For the period 1983-1985 the peak of the series is age 55 when the union membership rate was 27.8\%. By 2016-2018 the peak of the series was at age 57 
where the membership rate was $14.3 \%$. A similar picture is seen in Chart 7 which does the equivalent for the United Kingdom. Once again, the peak flattened.

In both countries the flattening of the peak is in fact akin to a souffle effect, in that the entire function moves down approximately together. The delicious soufflé rises and when it has fully formed and cools it deflates roughly evenly. In Chart 6 at age 55 the yellow line for 1983-1985 has a membership rate of $27.8 \%$ versus $13.3 \%$ in 2016-2018. This compares with $18.7 \%$ at 30 in the first period and $9.4 \%$ in the most recent period. Both ages have seen the probabilities approximately halving. In Chart 7 for the UK the membership rate at age 46 is $36.1 \%$ in the earliest period versus $24.4 \%$ in the later period. At age 30, membership rates are $31.5 \%$ and $18.0 \%$ respectively.

We now turn to plot the age peaks over time for the United States and the United Kingdom, and both show the peak rises over time. In Chart 8 for the United States we use the MORG data, 19832018. We include controls for state, year, and month of interview, gender, race and private sector. Chart 8 also includes the equivalent plot for the United Kingdom using the LFS, 1992-2019. Controls here are region, gender, race and labour market status. Again, as throughout this paper, the chart is confined to those who are working.

The peak rises even more sharply in the UK than it did in the United States rising over time from 46 in 1992 to 53 in 2019. It turns out that this movement of the peak to the right is driven by the facts noted above, in both countries, because union density rates of those age 65 and above have been rising over time. In part this reflects the rising labor force participation rates of these groups.

The flattening of the peak in age and its movement to the right has been accompanied by declines in union density in both countries that have broadly similar paths. Bryson, Gomez and Willman (2010b) examined union density rates in the United Kingdom and the United States and showed there were broadly common paths, although with the United States always having a lower rate, from around 1910 to 1960. Density rates in both picked up in World War One fell through the mid-1930s and then rose through 1960. ${ }^{17}$ The big difference is that the United States reached a peak in 1960 and then the paths diverged. Chart 9 plots union density rates from Jelle Visser's ICTWSS database on international union data around the world at the University of Amsterdam (https://www.ictwss.org). ${ }^{18}$ It shows that in contrast to the United States the United Kingdom reached its peak in 1980, along with other European countries that saw big rises in unionism in the years after the Paris riots of $1968 .{ }^{19}$

17 We update using data for the US from www.unionstats.com and for the UK from https://www.gov.uk/government/statistics/trade-union-statistics-2019. Of interest in the UK is that the union membership numbers closely track the rates (Table 1). In thousands $1920=8,348 ; 1930=4,842 ; 1940=6,613$; $1950=9,289 ; 1960=9,835 ; 1970=11,179 ; 1979$ (peak) $=13,212 ; 1980=12,636 ; 1990=9810 ; 2000=7,779 ; 2010=7,261 ;$ $2017=6,768$

${ }^{18}$ For further discussion of union density across countries see Visser, (2002, 2006, 2019) and Ebbinghaus and Visser (1999).

${ }^{19}$ Examples are, with rates in 1968 alongside rates for 1980 in parentheses from ICTWSS - Belgium 42 (54); Denmark 59 (78); Finland 41 (69); Italy 31 (50); Sweden 66 (78) and UK 41 (52). 
Below we show the union membership rate, weighted by the sample weights, in our data since 2000 by birth cohort for the two countries. Union density falls as the older cohorts leave the labor force.

$\begin{array}{lrc} & \text { US } & \text { UK } \\ 1940-49 & 10.3 & 15.9 \\ 1950-59 & 14.5 & 27.7 \\ 1960-69 & 13.7 & 28.3 \\ 1970-79 & 12.3 & 23.5 \\ 1980-89 & 9.4 & 18.3 \\ 1990+ & 4.4 & 10.0 \\ \text { Total } & 11.1 & 22.0\end{array}$

\section{Discussion and Conclusions}

We have reported inverted U-shapes in age in union membership equations in sixty-eight countries from around the world including the vast majority of EU countries plus the United States, the United Kingdom, Canada Japan, China, India and New Zealand. ${ }^{20}$ We make use of eight major survey series and, in six of these, we use several sweeps of the same data. Previous studies clearly established the decline in union membership due to birth cohort effects, with more recent generations less likely to join trade unions, resulting in a rise in never-membership. But this paper confirms a life-cycle effect within as well as across cohort, with individuals increasingly likely to be unionized until midlife, after which their unionization rate declines.

We found the association in all fifty states in the United States plus the District of Columbia, in both Right-to-Work law states and those with no such laws. We even found membership peaked in midlife in seven states that switched RTW status, both before and after the switch. If the age at which workers are, or are not union members, follows a similar life-cycle pattern everywhere, as these findings suggest, then it seems that labor market institutions matter little.

However, we also find that the height of the midlife peak has been falling in both the United States and the United Kingdom, the only two countries for which we have a long time series with a sizeable number of worker observations. The fact that union membership rates have been declining most rapidly among the group who are most likely to be union members - the middleaged - is a major reason for the decline in union density across the world, one which has not been commented upon to date.

The obvious question is why is there this stable pattern of union density by age peaking in midlife across countries? If we return to Blanchflower's (2007) ten potential reasons, we have already dismissed the proposition that these reflect cohort effects: although cohort effects exist, membership also follows a life-cycle pattern, peaking in midlife, regardless of cohort.

\footnotetext{
${ }^{20}$ Andorra; Armenia; Austria; Azerbaijan; Belarus; Belgium; Bolivia; Bosnia; Brazil; Bulgaria; Cambodia; Canada; Chile; China; Croatia; Cyprus; Czech Republic; Denmark; Ecuador; Finland; France; Georgia; Germany; Hong Kong; Hungary; Iceland; India; Ireland; Israel; Italy; Japan; Kyrgyzstan; Lebanon; Luxembourg; Macau SA; Malaysia; Mali; Montenegro; Nepal; Netherlands; New Zealand; Nigeria; Norway; Palestine; Poland; Portugal; Romania; Russia; Rwanda; Singapore; Slovakia; Slovenia; South Africa; South Korea; Spain; Suriname; Sweden; Switzerland; Taiwan; Tanzania; Tunisia; Turkey; Ukraine; United Kingdom; Uruguay; USA; Vietnam and Yugoslavia.
} 
The second possibility is that age-membership patterns reflect broader life-cycle patterns. There is growing evidence that other variables reach a peak in midlife. In the United States Case et al. (2020) have noted that deaths of despair - from suicide, drug and alcohol poisonings disproportionately occur in midlife. Misery peaks in midlife (Blanchflower and Oswald, 2020) as does the taking of anti-depressants (Blanchflower and Oswald, 2016). Happiness reaches a nadir in midlife and unhappiness reaches a zenith (Graham and Pozuelo, 2019). Even great apes have a midlife slump in happiness (Weiss, 2018). Blanchflower (2020a) found in a study of 145 countries that happiness reached a midlife nadir at age 48, and Blanchflower (2020b) using twenty measures of unhappiness found it reached a mid-life zenith at the same age. ${ }^{21}$

Crucially from a worker perspective, job satisfaction is also U-shaped in age, reaching its low point in workers' late 20 s or early 30 s - so a little earlier than the high point in union membership (Blanchflower and Bryson, 2020). It may be that workers stick with trade unions in their late 20s and 30s when their job satisfaction is at its lowest, in the hope that their union will improve their lot. As their wellbeing begins to rise in their late 40s and early 50s, perhaps this is the moment at which the net benefits of union membership look less attractive? After all, by this point they should have accrued the union-procured benefits associated with bargaining for higher wages and pension rights, while the amenity of the insurance component of the union good is a declining function of time left to retirement (put simply, the value of insurance from arbitrary employer behavior is considerably higher in one's 20 s and 30 s than it is much later in life when one is approaching retirement).

Further evidence of lifecycle returns to union membership were provided by Blanchflower and Bryson $(2003,2004)$ who estimated the union membership wage premium in the United States and the United Kingdom in age cells: they show the premium is higher among younger workers than it is among older workers.

If, as we suggest above, older workers have less 'need' for unions than their prime-age or younger counterparts, it may be economically rational for them to simply quit membership and save their union dues. If this were so it would manifest itself in a higher exit rate from union membership among 'ever-members', that is, those who are currently or who have ever been union members. To investigate whether this is the case we run linear estimation models with country fixed effects for the $(0,1)$ outcome of being an ex-member among ever-members whose main activity is paid work. We do so by pooling the 80,593 observations from 31 countries in the European Social Survey over the period 2002-2016. The pooled regression, which only contains age and age squared, alongside country fixed effects, accounts for $22 \%$ of the variance in ex-membership. Conditioning on country fixed effects, the rate of ex-membership is flat across most of the lifecycle but rises later in life from around the age of $50 .^{22}$

\footnotetext{
${ }^{21}$ There have however, been dissenters from the view that there is a midlife crisis in well-being (Blanchflower and Graham, 2020).

22 The age coefficient is positive but statistically non-significant with a t-stat of 0.98 but the age squared term is positive and statistically significant with a t-stat of 3.68. Of course, we do not have the timing of their departure from union membership because we have no panel data and no retrospective information. So this issue could be usefully investigated further with panel data. Results available from the authors.
} 
It is conceivable that in many countries leaving union membership in this way is particularly beneficial financially since members may continue to benefit from union bargaining coverage which arises through workplace, firm, sectoral or national bargaining - because bargained terms and conditions are extended to non-members and - unless they live in a regime such as the nonRTW states of the United States - they will not be charged a fee reflecting the union's cost of procuring those public goods. However, it is not obvious why there are additional incentives for workers beyond midlife to become 'free-riders'. Although, to our knowledge, nobody has examined this issue, work that has been done on the probability of being a free-rider suggests, if anything, that the probability falls later in life (see Bryson, 2008 for the United Kingdom and New Zealand).

A further possible explanation for the decline seen in union membership rates after midlife is the well-known correlation between the age of workers and the age of the workplaces that employ them. Studies find older (younger) workers tend to sort into, or are hired by, older (younger) workplaces. Machin (2002) argues that it is the age of the workplace that is the crucial age-based factor behind union decline. Its omission from the social surveys we examine may lead to omitted variables bias, with age potentially proxying age of workplace. However, as Machin (2002) makes clear, the workplace effect is really a cohort effect, with workplace in the early post-war period having a higher likelihood of being unionized. This effect, previously documented by Millward et al. (2000), has subsequently received great attention in the worker voice literature with newer workplaces switching away from union-based voice towards non-union direct forms of voice such as team briefings (Bryson et al., 2019). However, since most of the estimates presented in this paper contain cohort effects, these are liable to account for Machin's (2002) point.

A stronger test of the role played by worker sorting into older and younger workplaces or industries is to estimate the association between worker age and union membership within the workplace. In order to examine this phenomenon, we turn to an analysis of an establishment level survey, the British Workplace Employment Relations Survey (WERS). ${ }^{23}$ We pooled the linked employeremployee data from the 2004 and 2011 surveys and run simple linear regression estimates on the probability of being a union member and workplace fixed effects on 44,432 employees in 3,056 workplaces. The adjusted R-squared with the workplace fixed effects is 0.40 . In both the OLS and workplace fixed effects models, membership rises with age, peaking when employees are in their 50s before declining from age 60 onwards. This is the case when one runs raw correlations (with a year dummy only), and if one adds controls for sex, education and region. The fact that union membership peaks in midlife before declining within workplaces, at least in Britain, indicates that the pattern is not accounted for by selection into different types of workplace. ${ }^{24}$

Other reasons Blanchflower (2007) suggests for the peak in membership in midlife relate to union workers leaving their union jobs. This may occur if they have a higher probability of moving to unemployment or labour market inactivity than non-union workers, as might be the case, for example, if employers single them out for dismissal because they are more expensive than 'like' non-members, or because they are more likely to be in workplaces that close. Alternatively, some union workers may gain promotion to managerial jobs and other positions that are, traditionally, less likely to be unionized.

\footnotetext{
${ }^{23}$ For full details on this survey go to https://www.wers2011.info/home and van Wanrooy et al. (2013).

${ }^{24}$ Results available on request from the authors.
} 
Another possibility is that it is a subset of union members who quit after midlife because seniority wages and wage compression rules reduce their potential earnings later in life, such that these most productive workers quit membership at that point. These propositions, which are best investigated with panel data tracking individuals through time, have not been tested in the literature. ${ }^{25}$

The hill shape in age in union membership is a remarkably consistent pattern in the data, maximizing around age fifty everywhere. Our estimates show that it is present in 68 countries with very different bargaining institutions, and high union density rates such as Norway, Sweden, and Finland where bargaining is centralized. It is also present in France where there is low membership as well as in the United States and the United Kingdom. We found it in all fifty states in the United States plus the District of Columbia, whether these dates were Right-To-Work states or not, including in South Carolina where private sector union density was $1.3 \%$ in 2019 . It is also found in a large number of developing countries, including China and India, Nigeria, Rwanda, Russia, Azerbaijan, Kyrgyzstan, Nepal and Malaysia.

In a set of experiments that we conducted in the United States and the United Kingdom, we found in both the peak of the hill-shape has come down over time as union density declined. The age at which union membership peaked has increased over time, not least because the one group whose rates are increasing are older workers over the age of sixty-five. If labor market institutions mattered, we would have expected to see big differences in union density by age across countries. We don't. Globalization seems to imply that labour markets no matter what their institutional structures are more similar than previously thought.

\footnotetext{
25 There is a literature on union effects on workplace survival and employment growth. Evidence on union closure effects is contested but the weight of evidence suggests unions do not increase the probability of workplace closure (Bryson, 2004a; Machin, 1995). Unions are also associated with lower rates of employment growth (Bryson, 2004b; Blanchflower, Milward and Oswald, 1991, Blanchflower and Millward, 1988).
} 


\section{References}

Beck, M. and Fitzenberger, B. (2004). Changes in union membership over time: a panel analysis for West Germany, Labour, 18 (3): 329-362.

Bennett, J. T. and Kaufman, B. E. (2007) What Do Unions Do? A Twenty-Year Perspective, Transaction Publishers, New Brunswick USA and London UK

Blanchflower, D.G. (2020a). Is happiness U-shaped? Age and subjective well-being in 145 countries. Journal of Population Economics. http://hdl.handle.net/10419/216108

Blanchflower, D.G. (2020b). Unhappiness and age. Journal of Economic Behavior and Organization, 176, 461-488. doi:10.1016/j.jebo.2020.04.022.

Blanchflower, D.G. (2007). International patterns of union membership. British Journal of Industrial Relations, 45:1: 1-28.

Blanchflower, D.G and Bryson, A. (2003). Changes over time in union relative wage effects in the UK and the US revisited'. In J. T. Addison and C. Schnabel (eds.), International Handbook of Trade Unions. Cheltenham, UK: Edward Elgar, pp. 197-245.

Blanchflower, D.G and Bryson, A. (2004). What effect do unions have on wages now and would Freeman and Medoff be surprised? Journal of Labor Research, XXV (3): 383414.

Blanchflower, D.G and Bryson, A. (2020) Now Unions Increase Job Satisfaction and Wellbeing., mimeo

Blanchflower, D.G. and Graham, C. (2020). The mid-life dip in well-being: economists (who find it) versus psychologists (who don't)! NBER Working Paper \#26888. doi:10.3386/w26888.

Blanchflower, D.G. and Millward, N. (1988). Trade unions and employment change: an analysis of British establishment data. European Economic Review, 32: 717-726.

Blanchflower, D.G. and Oswald, A.J. (2020). American misery: the rise of extreme distress in the USA, 1993-2019. American Journal of Public Health, forthcoming.

Blanchflower, D.G. and Oswald, A.J. (2016). Antidepressants and age: a new form of evidence for U-shaped well-being through life. Journal of Economic Behavior and Organization, 127, 46-58.

Blanchflower, D.G. and Oswald, A.J. (2008). Is well-being U-shaped over the life cycle? Social Science and Medicine, 66(8), 1733-1749.

Blanchflower, D.G., Oswald, A.J. and Millward, N. (1991). Unionism and employment behavior, Economic Journal, 101(407): 815-834. 
Booth, J. E., Budd, J. W. and Munday, K. M. (2010) "Never say never? Uncovering the never-unionized in the United States", British Journal of Industrial Relations, 48(1): $26-52$

Bryson, A. (2004a). Union effects on workplace closure, 1990-1998, British Journal of Industrial Relations, Vol. 42, 2: 283-302.

Bryson, A. (2004b). Unions and employment growth in British workplaces during the 1990s: A Panel Analysis, Scottish Journal of Political Economy, Vol. 51, No. 4, 477-506.

Bryson, A. (2008). Union free-riding in Britain and New Zealand, Journal of Industrial Relations, 50, 1, 5-24.

Bryson, A. and Davies, R. (2019) "Family, place and the intergenerational transmission of union membership", British Journal of Industrial Relations, 57, 3: 624-650.

Bryson, A., Freeman, R., Gomez, R. and Willman, P. (2019) "The twin track model of employee voice: an Anglo-American perspective on union decline and the rise of alternative forms of voice", in Holland, P., Teicher, J. and Donaghey, J. (eds.) Employee Voice at Work, Springer, pp. 23-50.

Bryson, A. and Gomez, R. (2005) Why have workers stopped joining unions: Accounting for the rise in never-membership in Britain? British Journal of Industrial Relations, 43:1, 67-92.

Bryson, A., Gomez, R., Gunderson, M., and Meltz, N. (2005) 'Youth adult differences in demand for unionization: are American, British and Canadian workers all that different?', Journal of Labor Research, Vol. 26, No. 1, 155-167.

Bryson, A., Gomez, R. and Willman, P. (2010a) 'Online social networking and trade union membership: what the Facebook phenomenon truly means for labor organizers', Labor History, 51, 1: 41-53

Bryson, A., Gomez, R., and Willman, P. (2010b). Voice in the wilderness? The shift from union to non-union voice in Britain. In Wilkinson, A. P.J. Gollan, M. Marchington, and D. Lewin (Eds.). The Oxford Handbook of Participation in Organizations, Oxford University Press, Oxford.

Case, A., Deaton, A., and Stone, A.A. (2020 [in press]). The mystery of American pain: why are the middle-aged in more pain than the elderly? Proceedings of the National Academy of Sciences.

Ebbinghaus, B. and Visser, J. (1999). When institutions matter: union growth and decline in Western Europe, 1950-1995. European Sociological Review, 15(2), June: 135-158. 
Freeman, R. and Kleiner, M. M. (1999). Do unions make enterprises insolvent? Industrial and Labor Relations Review, 52: 510-527.

Graham, C., and Pozuelo, J. R. (2017). Happiness, stress, and age: How the U curve varies across people and places. Journal of Population Economics, 30, 225-264.

Lind, J. T. and Mehlum, H. (2010). With or without U? The appropriate test for a U-shaped relationship. Oxford Bulletin of Economics and Statistics, 72(1), 109-118.

Machin, S. (1995). Plant closures and unionization in British establishments, British Journal of Industrial Relations, 33(1): 55-68.

Machin, S. (2002). Union decline in Britain, British Journal of Industrial Relations, 38, 4: 631645.

Millward, N., Bryson, A. and Forth, J. (2000) All Change at Work? Routledge, London.

Nergaard, K. and Stokke, T.A. (2007). The puzzles of union density in Norway. Transfer: European Review of Labour and Research, 13(4): 653-670. https://doi.org/10.1177/102425890701300409

Office of National Statistics (2019) Trade union membership, UK 1995-2019: Statistical Bulletin. https://assets.publishing.service.gov.uk/government/uploads/system/uploads/attachm ent data/file/887740/Trade-union-membership-2019-statistical-bulletin.pdf

Posthuma, R.A. (2009). National culture and union membership: a cultural-cognitive perspective Industrial Relations, 64(3): 507-529. https://doi.org/10.7202/038554ar

Schnabel, C. (2003). Determinants of trade union membership. In J. Addison and C. Schnabel (eds.), The International Handbook of Trade Unions. Cheltenham: Edward Elgar, pp. 1343.

Schnabel, C. and Wagner, J. (2012). With or without U? Testing the hypothesis of an Inverted Ushaped union membership-age relationship. Contemporary Economics, 6(4): 28-34.

van Wanrooy, B., Bewley, H., Bryson, A., Forth, J., Stokes, L. and Wood, S. (2013) Employment Relations in the Shadow of Recession: Findings from the 2011 Workplace Employment Relations Study, Palgrave MacMillan

Visser, J. (2019). Trade unions in the balance. Geneva: International Labour Organization ACTRAV Bureau for Workers' Activities Working Paper, Geneva. http://relats.org/documentos/OIT.FT.Visser.feb.pdf

Visser, J. (2006). Union membership statistics in 24 countries, Monthly Labor Review, January: $38-49$. 
Visser, J. (2002). Why fewer workers join unions in Europe: A social custom explanation of membership trends, British Journal of Industrial Relations, 40(3): 403-430.

Waddington, J. and Kerr, A. (2008) “Unions fit for young workers?”, Industrial Relations Journal, 33 (4): 298-315

Weiss, A., King, J.E., Inoue-Murayama, M., Matsuzawa, T., and Oswald, A.J. (2012). Evidence for a midlife crisis in great apes consistent with the U-shape in human well-being. Proceedings of the National Academy of Sciences, 109(49), 19949-19952. doi:10.1073/pnas.1212592109

Willman, P., Bryson, A. and Forth, J. (2020). UK trade unions and the problem of collective action, British Journal of Industrial Relations, 58(2): 447-470. 
Table 1. OLS Union membership equations in the United States

\begin{tabular}{|c|c|c|c|c|c|c|}
\hline & All & All & $\begin{array}{c}\text { Private } \\
\end{array}$ & $\begin{array}{c}\text { Public } \\
\text { Pa }\end{array}$ & $\begin{array}{c}\text { GUSDT } \\
01098(3745)\end{array}$ & $\begin{array}{c}\text { GSS } \\
0055(847)\end{array}$ \\
\hline Age & $.0121(225.72)$ & $.0124(164.87)$ & $.01071(142.19)$ & $.03162(109.12)$ & $.01098(37.45)$ & $.0055(8.47)$ \\
\hline $\operatorname{Age}^{2 *} 100$ & $-.0125(197.41)$ & $-.0129(174.59)$ & $-.01105(145.49)$ & $-.03500(121.47)$ & $-.01159(39.23)$ & $-.0054(7.29)$ \\
\hline Male & $.0551(212.14)$ & $.0561(216.28)$ & $.06199(245.75)$ & .01966 (22.81) & $.00296(5.51)$ & $.0356(12.22)$ \\
\hline Private & $-.2596(745.80)$ & $-.2577(740.21)$ & - & & & \\
\hline Cohort dummi & No & Yes & Yes & Yes & Yes & Yes \\
\hline Adjusted $\mathrm{R}^{2}$ & .1366 & .1373 & .0536 & .1577 & .0371 & -.1372 \\
\hline $\mathrm{N}$ & $6,179,923$ & $6,179,923$ & $5,085,546$ & $1,067,907$ & $1,434,653$ & $1,341,685$ \\
\hline Age maximum & n $\quad 48$ & 47 & 48 & 45 & 47 & 51 \\
\hline
\end{tabular}

Notes: Columns 1-4 MORG, 1983-2018; column 5 GUSDT, 2008-2017; column 6. GSS 1972-2018.

All equations include 5 race dummies, 50 state dummies, 11 interview month and 35-year dummies. For GSS 8 region dummies included 
Table 2. Age zeniths in union membership in US states by Right-To-Work laws, 1983-2018.

\begin{tabular}{|c|c|c|c|c|c|}
\hline Switchers & $\begin{array}{c}\text { RTW } \\
\text { Age maximum }\end{array}$ & $\mathrm{N}$ & & $\begin{array}{r}\text { Non-RTW } \\
\text { Age maximum }\end{array}$ & $\mathrm{N}$ \\
\hline Idaho & 50 & 90,260 & Idaho & 60 & 4,098 \\
\hline Indiana & 43 & 91,480 & Indiana & 47 & 76,899 \\
\hline Kentucky* & 49 & 3,890 & Kentucky & 48 & 72,978 \\
\hline Michigan & 54 & 78,061 & Michigan & 48 & 172,362 \\
\hline Oklahoma & 44 & 68,648 & Oklahoma & 48 & 39,183 \\
\hline West Virginia & 44 & 75,417 & West Virginia & 50 & 62,574 \\
\hline Wisconsin & 56 & 83,045 & Wisconsin & 44 & 99,145 \\
\hline \multicolumn{6}{|l|}{ Non-switchers } \\
\hline RTW & & & Non-RTW & & \\
\hline RTW & 47 & $2,348,713$ & Non RTW & 48 & $3,831,210$ \\
\hline Alabama & 47 & 18,9423 & Alaska & 47 & 81,946 \\
\hline Arizona & 50 & 25,808 & California & 50 & 474,114 \\
\hline Arkansas & 46 & 10,087 & Colorado & 51 & 102,930 \\
\hline Florida & 47 & 98,351 & Connecticut & 48 & 94,269 \\
\hline Georgia & 42 & 84,365 & $\mathrm{DC}$ & 56 & 75,584 \\
\hline Iowa & 46 & 86,980 & Delaware & 46 & 76,840 \\
\hline Kansas & 47 & 117,079 & Hawaii & 48 & 76,624 \\
\hline Louisiana & 44 & 175,781 & Illinois & 47 & 230,917 \\
\hline Mississippi & 47 & 106,770 & Maine & 49 & 81,197 \\
\hline Nebraska & 49 & 251,278 & Maryland & 47 & 106,209 \\
\hline Nevada & 48 & 3,890 & Massachusetts & 46 & 168,937 \\
\hline North Carolina & 44 & 81,851 & Minnesota & 49 & 113,673 \\
\hline North Dakota & 45 & 78,031 & Missouri & 47 & 90,433 \\
\hline South Carolina & 41 & 73,058 & Montana & 47 & 73,367 \\
\hline South Dakota & 46 & 69,674 & New Hampshire & 42 & 94,047 \\
\hline Tennessee & 48 & 37,341 & New Jersey & 47 & 190,411 \\
\hline Texas & 46 & 301,813 & New Mexico & 45 & 66,877 \\
\hline Utah & 46 & 72,607 & New York & 50 & 328,774 \\
\hline Virginia & 49 & 74,131 & Ohio & 49 & 221,955 \\
\hline \multirow[t]{5}{*}{ Wyoming } & 50 & 84,606 & Oregon & 49 & 76,847 \\
\hline & & & Pennsylvania & 47 & 231,350 \\
\hline & & & Rhode Island & 53 & 79,577 \\
\hline & & & Vermont & 54 & 76,033 \\
\hline & & & Washington & 53 & 91,410 \\
\hline
\end{tabular}

Notes: the dates for the seven states that switched from non RTW to RTW were as follows Idaho=1985; Indiana=2012; Kentucky=2017; Michigan=2012; Oklahoma=2001; West Virginia $=2016$ and Wisconsin $=2015$.

*As there were only two years of data for Kentucky the estimate there excludes cohort dummies. 
Table 2a. Union membership in the 2000-2018 MORG by industry

Age maximum

2000-2018

Private

Public

Agric

Construction

Manufacturing

Wholesale trade

Retail trade

Transportation

Information

FIRE

Professional services

Educational services

Arts, entertainment

Other services

Public administration
49

50

46

51

48

54

51

51

51

51

55

57

50

55

46

42
$\mathrm{N}$

$3,242,682$

$2,693,029$

549,650

57,538

190,286

374,816

89,067

375,515

171,121

77,107

216,690

305,705

765,696

292,557

141,516

182,086

From Census Basic Monthly CPS website

https://www2.census.gov/programs-

surveys/cps/datasets/2020/basic/2020 Basic CPS Public Use Record Layout plus IO Code list.txt

0010 - 0560 Agriculture, Forestry, Fishing and Hunting, and Mining

0770 - 1060 Construction

1070 - 4060 Manufacturing

4070 - 4660 Wholesale Trade

4670 - 6060 Retail Trade

6070 - 6460, 0570 - 0760 Transportation and Warehousing, and Utilities

6470 - 6860 Information

6870 - 7260 Finance and Insurance, and Real Estate and Rental and Leasing

7270 - 7790 Professional, Scientific, and Management, and Administrative and Waste Management Services

7860 - 8490 Educational Services, and Health Care and Social Assistance

8560 - 8690 Arts, Entertainment, and Recreation, and Accommodation and Food Services

8770 - 9290 Other Services (except Public Administration)

9370 - 9590 Public Administration 
Table 3. OLS Union membership equations in the UK

\begin{tabular}{|c|c|c|c|c|c|}
\hline & All & All & Private & Public & All \\
\hline Age & $.0291(181.27)$ & .0264 (111.72) & $.0142(60.65)$ & $.0372(62.90)$ & $.0236(92.45)$ \\
\hline $\mathrm{Age}^{2 *} 100$ & $-.0296(155.12)$ & $-.0263(109.74)$ & $-.0134(56.86)$ & $-.0400(65.75)$ & $-.0226(87.53)$ \\
\hline Male & $-.0011(1.58)$ & -.0009 (1.24) & $.0574(62.48)$ & $.0339(20.84)$ & -.0009 (1.19) \\
\hline Self-employed & $-.2331(216.48)$ & $-.2329(216.38)$ & $-.1259(130.28)$ & $-.2609(42.58)$ & $-.2365(216.68)$ \\
\hline $\begin{array}{l}\text { Training program } \\
\text { ALS }\end{array}$ & $-.1149(18.46)$ & $-.1192(19.15)$ & $-.0630(9.65)$ & $-.3464(23.77)$ & $\begin{array}{r}-.1202(18.78) \\
.0133(93.82)\end{array}$ \\
\hline Cohort dummies & No & Yes & Yes & Yes & Yes \\
\hline Adjusted $\mathrm{R}^{2}$ & .0788 & .0795 & .0506 & .0572 & .0316 \\
\hline $\mathrm{N}$ & $1,385,113$ & $1,385,113$ & 932,536 & 384,885 & $1,338,720$ \\
\hline Age maximum & 49 & 50 & 53 & 47 & 52 \\
\hline
\end{tabular}

Notes: LFS 1992-2019. Private sector variable available from 1993. All equations include 20 region dummies, 5 race dummies and 27-year dummies.

Union membership in the 1992-2019 LFS by Region and Country

$\begin{array}{lcr}\text { UK } & 50 & 1,385,113 \\ \text { North East } & 50 & 57,573 \\ \text { Merseyside } & 49 & 150,539 \\ \text { Yorkshire \& Humberside } & 50 & 121,079 \\ \text { East Midlands } & 49 & 103,497 \\ \text { West Midlands } & 49 & 121,499 \\ \text { Eastern } & 51 & 137,624 \\ \text { London } & 56 & 139,637 \\ \text { South East } & 50 & 203,377 \\ \text { South West } & 51 & 123,086 \\ \text { Wales } & 50 & 63,130 \\ \text { Scotland } & 50 & 120,979 \\ \text { Northern Ireland } & 48 & 44,093\end{array}$


Table 4. European Social Survey OLS union membership equations 2002-2018

\begin{tabular}{|c|c|c|c|c|}
\hline & All & All & All & Germany \\
\hline Age & $.0180(35.96)$ & $.0190(42.75)$ & $.0197(27.38)$ & $.0091(3.12)$ \\
\hline $\mathrm{Age}^{2 *} 100$ & $-.0156(27.13)$ & $-.0172(33.69)$ & $-.0186(24.55)$ & $-.0084(2.75)$ \\
\hline Male & $.0071(3.66)$ & $-.0044(2.57)$ & $-.0044(2.54)$ & $.0702(10.56)$ \\
\hline Native & .0425 (13.01) & .0499 (16.86) & $.0494(16.71)$ & $.0423(3.70)$ \\
\hline Years education & .0118 (44.75) & $.0071(29.05$ & $.0072(29.35)$ & $-.0007(0.06)$ \\
\hline Self-employed & $-.2087(73.35)$ & $-1982(78.05)$ & $-1971(77.54)$ & $-.1552(15.53)$ \\
\hline Family business & $-.2293(27.88)$ & $-.2138(29.31)$ & $-.2131(29.22)$ & $-.1339(3.50)$ \\
\hline Sweep dummies & No & Yes & Yes & Yes \\
\hline Country dummies & No & Yes & Yes & No \\
\hline Cohort dummies & No & No & Yes & Yes \\
\hline Constant & -.3551 & -.3817 & -.2476 & -.1142 \\
\hline Adjusted $\mathrm{R}^{2}$ & .0523 & .261 & .0354 & .0347 \\
\hline $\mathrm{N}$ & 204,214 & 204,214 & 204,214 & 12,488 \\
\hline Age maximum & 58 & 55 & 54 & 54 \\
\hline
\end{tabular}

Countries are Albania; Austria; Belgium; Bulgaria; Czech Republic; Cyprus; Croatia; Denmark; Germany; Estonia; Finland; France; Greece; Hungary; Iceland; Ireland; Israel; Italy; Kosovo; Latvia; Lithuania; Luxembourg; Montenegro; Netherlands; Norway; Poland; Portugal; Romania; Russia; Serbia; Slovakia; Slovenia; Spain; Sweden; Switzerland; Turkey; Ukraine and UK.

Individual country results below with controls as above - gender years education, native, wave and cohort dummies where both age and age squared $t$ statistics $>1.5$.

Age Maxima for Union membership by Country in the 2002-2018 European Social Survey

\begin{tabular}{lrrlll} 
& Max & \multicolumn{1}{c}{$\mathrm{N}$} & & Max & $\mathrm{N}$ \\
All & 53 & 204,214 & Luxembourg & 59 & 1,363 \\
Austria & 47 & 6,874 & Netherlands & 56 & 8,195 \\
Belgium & 52 & 7,792 & Norway & 59 & 8,866 \\
Bulgaria & 57 & 4,290 & Poland & 61 & 7,215 \\
Czech Republic & 53 & 8,803 & Portugal & 66 & 6,765 \\
Cyprus & 57 & 2,580 & Romania & 44 & 1,596 \\
Denmark & 46 & 5,886 & Russia & 41 & 6,522 \\
Finland & 51 & 8,982 & Slovakia & 55 & 4,461 \\
France & 65 & 6,555 & Slovenia & 47 & 5,236 \\
Germany & 59 & 12,488 & Spain & 68 & 7,258 \\
Hungary & 53 & 6,233 & Sweden & 52 & 9,036 \\
Iceland & 40 & 1,302 & Switzerland & 41 & 8,582 \\
Ireland & 57 & 8,899 & UK & 54 & 9,733 \\
Israel & 58 & 6,889 & Ukraine & 57 & 3,813 \\
Italy & 47 & 3,990 & & &
\end{tabular}


Table 5. World Values Survey OLS union membership equations Sweeps 1-7 workers

$\begin{array}{lccc}\text { Age } & .0087(24.13) & .0061(17.71) & .0073(15.39) \\ \text { Age }^{2 * 100} & -.0097(22.86) & -.0065(16.02) & -.0074(15.36) \\ \text { Male } & -.0046(2.92) & .0052(3.35) & .0050(3.23) \\ \text { Part-time } & & -.0271(12.21) & -.0274(12.36) \\ \text { Self-employed } & & -.0584(10.12) & -.0584(28.62) \\ & \text { No } & \text { Yes } & \text { Yes } \\ \text { Wave/country dummies } & \text { No } & \text { No } & \text { Yes } \\ \text { Cohort dummies } & -.0283 & .0273 & -.0358 \\ \text { Constant } & .0031 & .1227 & .1231 \\ \text { Adjusted R } & 200,380 & 200,380 & 200,380 \\ \mathrm{~N} & 45 & 47 & 49 \\ \text { Age maximum } & & & \end{array}$

Age maxima for union membership from country level results using column 3 specification with cohort dummies

\begin{tabular}{lrrlrr} 
& Max & \multicolumn{1}{c}{$\mathrm{N}$} & & Max & $\mathrm{N}$ \\
All & 45 & 200,380 & Nigeria & 39 & 2,929 \\
Andorra & 40 & 1,713 & Romania & 57 & 2,521 \\
Azerbaijan & 37 & 1,817 & Russia & 37 & 6,263 \\
Belarus & 50 & 2,141 & Singapore & 44 & 2,006 \\
Bolivia & 32 & 1,037 & Slovakia & 45 & 631 \\
Canada & 54 & 3,291 & Slovenia & 42 & 1,538 \\
Chile & 44 & 3,734 & South Africa & 41 & 5,489 \\
China & 55 & 7,697 & Spain & 45 & 2,702 \\
Cyprus & 57 & 1,735 & Sweden & 40 & 3,367 \\
Czech Republic & 31 & 606 & Switzerland & 48 & 2,322 \\
Ecuador & 39 & 1,329 & Taiwan & 47 & 2,891 \\
India & 44 & 4,494 & Tanzania & 36 & 608 \\
Japan & 50 & 5,911 & Turkey & 45 & 3,781 \\
Kyrgyzstan & 43 & 2,305 & Ukraine & 59 & 2,869 \\
Lebanon & 52 & 1,436 & USA & 50 & 7,770 \\
Malaysia & 40 & 2,664 & Vietnam & 60 & 1,950 \\
Montenegro & 46 & 621 & & &
\end{tabular}


Table 6. ISSP 2015 OLS union membership equations - workers age $<70$

$\begin{array}{lccc}\text { Age } & -.0198(27.10) & .0150(12.00) & .0141(11.39) \\ \text { Age }^{2 * 100} & .0025(27.54) & -.0147(10.12) & -.0125(8.68) \\ \text { Male } & -.0132(6.10) & .0128(2.84) & -.0013(0.29) \\ \text { Self no employees } & & & -.1581(20.64) \\ \text { Self with employees } & & & -.1664(15.09) \\ \text { Family's business } & & & -.1712(10.31) \\ \text { N/a lf status } & & & -.0617(3.99) \\ & \text { No } & \text { No } & \text { Yes } \\ \text { Education dummies } & \text { No } & \text { Yes } & \text { Yes } \\ \text { Country dummies } & .5941 & -.1035 & -.2068 \\ \text { Constant } & .0283 & .2645 & .2870 \\ \text { Adjusted R } \mathrm{R}^{2} & 27,071 & 27,071 & 27071 \\ \mathrm{~N} & 39 & 51 & 56 \\ \text { Age maximum } & .244 & & \\ \text { Mean } & & & \end{array}$

Notes: sample consists of those currently working

Age maxima for union membership from country level results using column 2 specification

$\begin{array}{lcrlrr} & \text { Age Max } & \text { N } & & \text { Age Max } & \text { N } \\ \text { All } & 56 & 27,071 & \text { Japan } & 36 & 897 \\ \text { Belgium } & 47 & 1,200 & \text { Lithuania } & 45 & 568 \\ \text { Chile } & 47 & 636 & \text { New Zealand } & 54 & 417 \\ \text { China } & 54 & 970 & \text { Slovenia } & 59 & 482 \\ \text { Czechia } & 51 & 760 & \text { Spain } & 49 & 870 \\ \text { Finland } & 57 & 654 & \text { Suriname } & 52 & 650 \\ \text { Georgia } & 57 & 431 & \text { Sweden } & 51 & 672 \\ \text { Israel } & 55 & 588 & \text { Taiwan } & 57 & 1,267\end{array}$

Countries (37) are - Australia; Austria; Belgium; Chile; China; Taiwan; Croatia; Chechia; Denmark; Estonia; Finland; France; Georgia; Germany; Hungary; Iceland; India; Israel; Japan; Latvia; Lithuania; Mexico; New Zealand; Norway; Philippines; Poland; Russia; Slovakia; Slovenia; South Africa; Spain; Suriname; Sweden; Switzerland; UK; USA and Venezuela 
Table 7. Asia and South Pacific - Gallup World Poll, 2010, 2012, 2013- workers

$\begin{array}{lccc}\text { Age } & .0072(12.15) & .0069(11.66) & .0068(11.56) \\ \text { Age }^{2 * 100} & -.0081(11.92) & -.0065(9.71) & -.0062(9.25) \\ \text { Male } & .0114(3.72) & .0050(1.64) & .0029(0.91) \\ \text { Self-employed } & & -.0889(26.90) & -.0881(25.92) \\ \text { PT wants FT } & & -.0787(15.97) & -.0761(15.40) \\ & & & \\ \text { Education dummies } & \text { No } & \text { Yes } & \text { Yes } \\ \text { Country/year dummies } & \text { No } & \text { No } & \text { No } \\ \text { Constant } & -.0347 & -.0359 & -.0897 \\ \text { Adjusted R } & .0031 & .0405 & .0612 \\ \mathrm{~N} & 46,071 & 46,071 & 46,071 \\ \text { Age maximum } & 44 & 53 & 55\end{array}$

Notes: excluded category employees

Country level results using column 3 specification

$\begin{array}{lrrlcr} & \text { Age Max } & \mathrm{N} & & \text { Age Max } & \mathrm{N} \\ \text { All } & 55 & 46,071 & \text { Japan } & 41 & 2,149 \\ \text { Australia } & 52 & 8,803 & \text { Nepal } & 43 & 1,602 \\ \text { Cambodia } & 39 & 1,919 & \text { New Zealand } & 54 & 1,503 \\ \text { China } & 55 & 9,675 & \text { Singapore } & 50 & 1,200 \\ \text { India } & 51 & 8,984 & \text { Taiwan } & 73 & 1,073\end{array}$

Countries are - Afghanistan; Australia; Bangladesh; Bhutan; Cambodia; China; Hong Kong; India; Indonesia; Japan; Laos; Malaysia; Mongolia; Myanmar; Nepal; New Zealand; Pakistan; Philippines; Singapore; South Korea; Sri Lanka; Taiwan; Thailand and Vietnam 


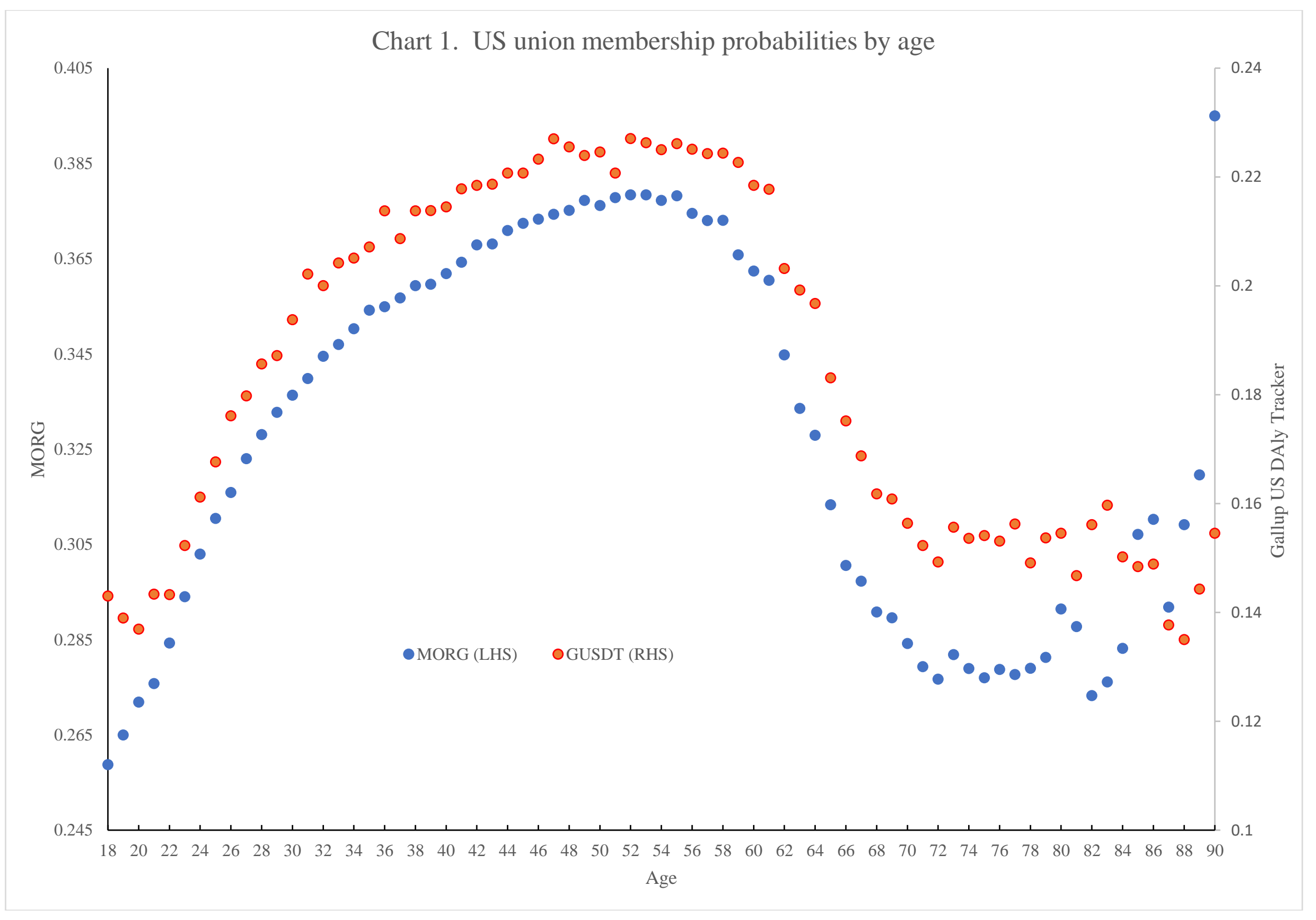




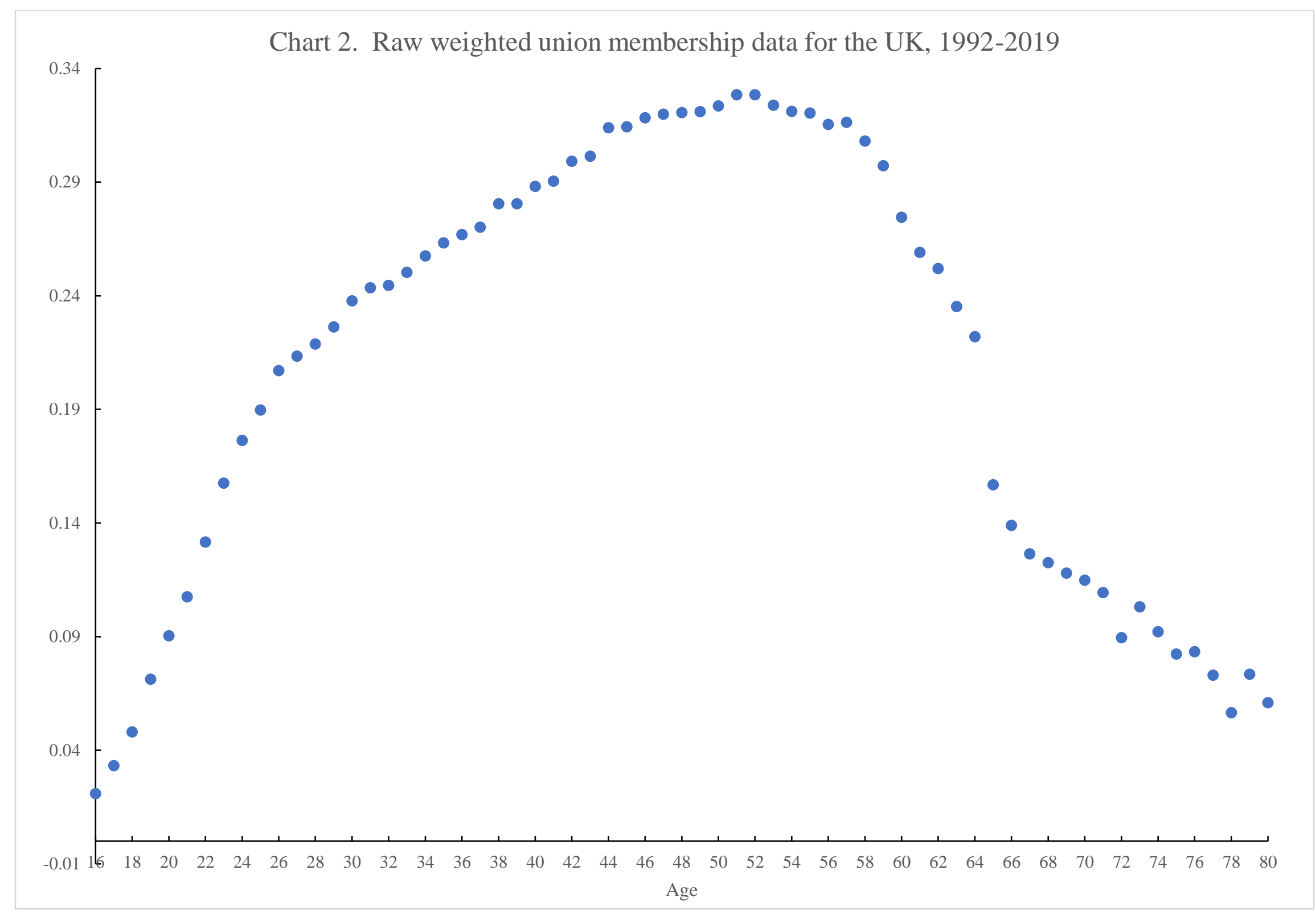




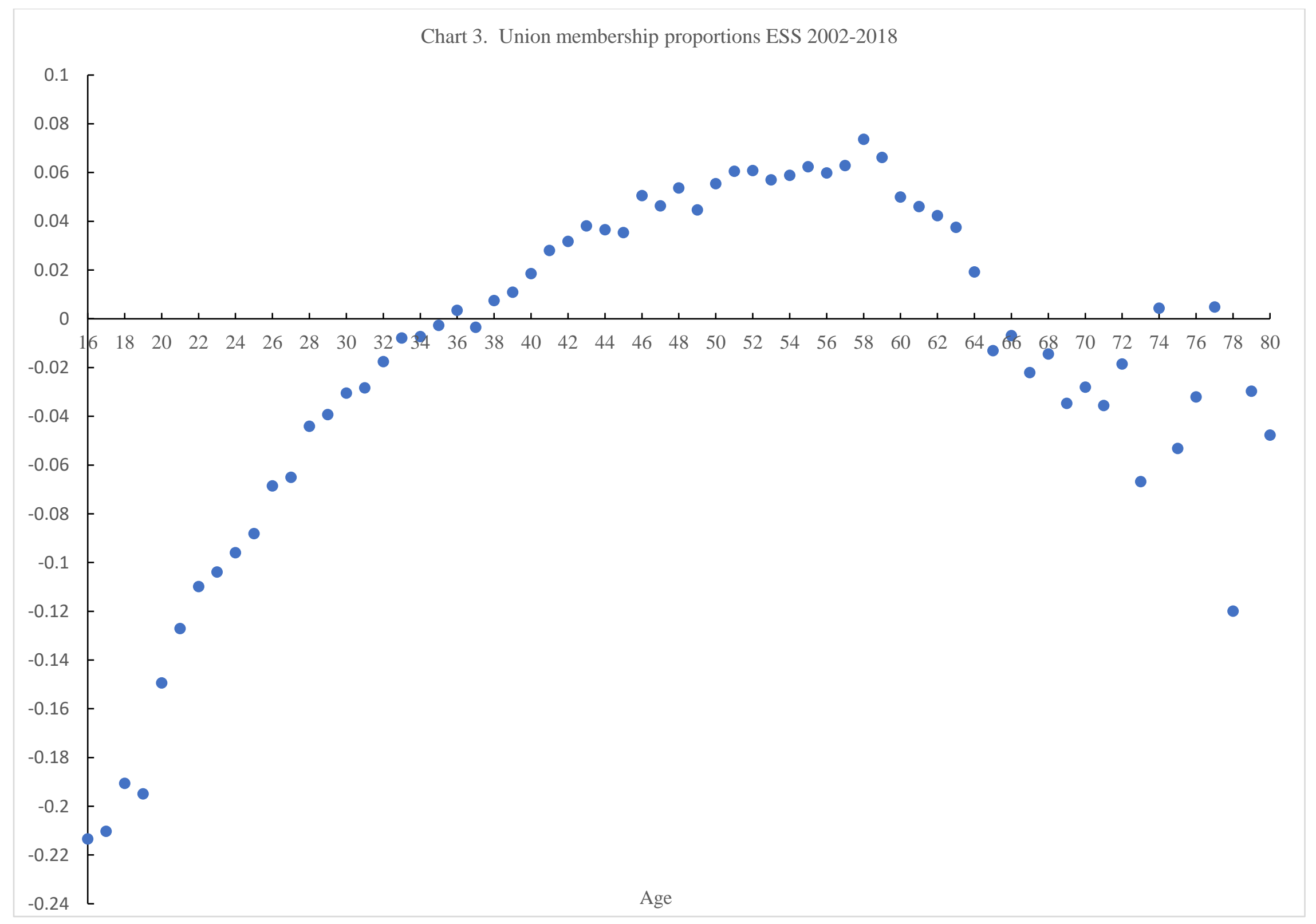




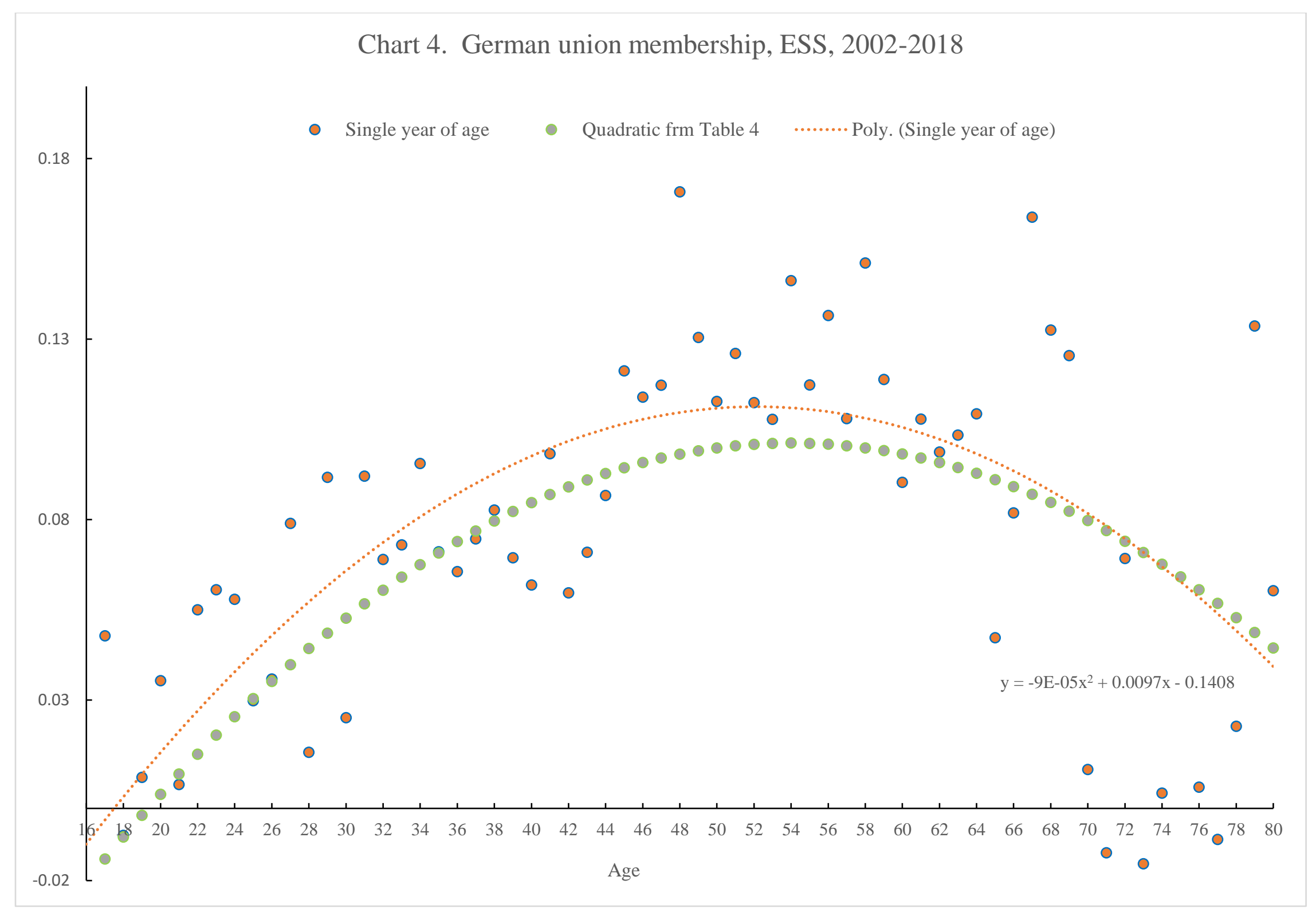




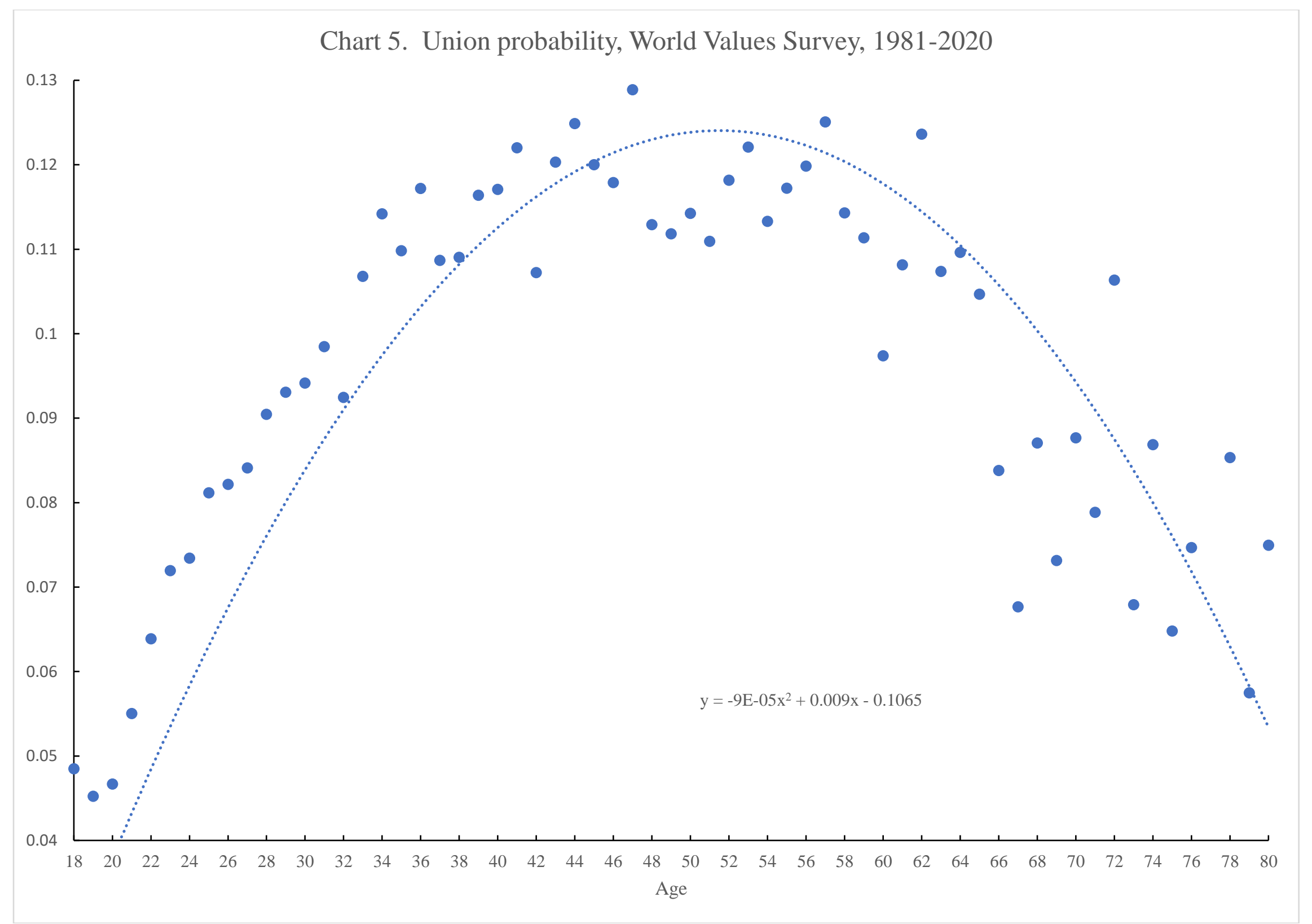




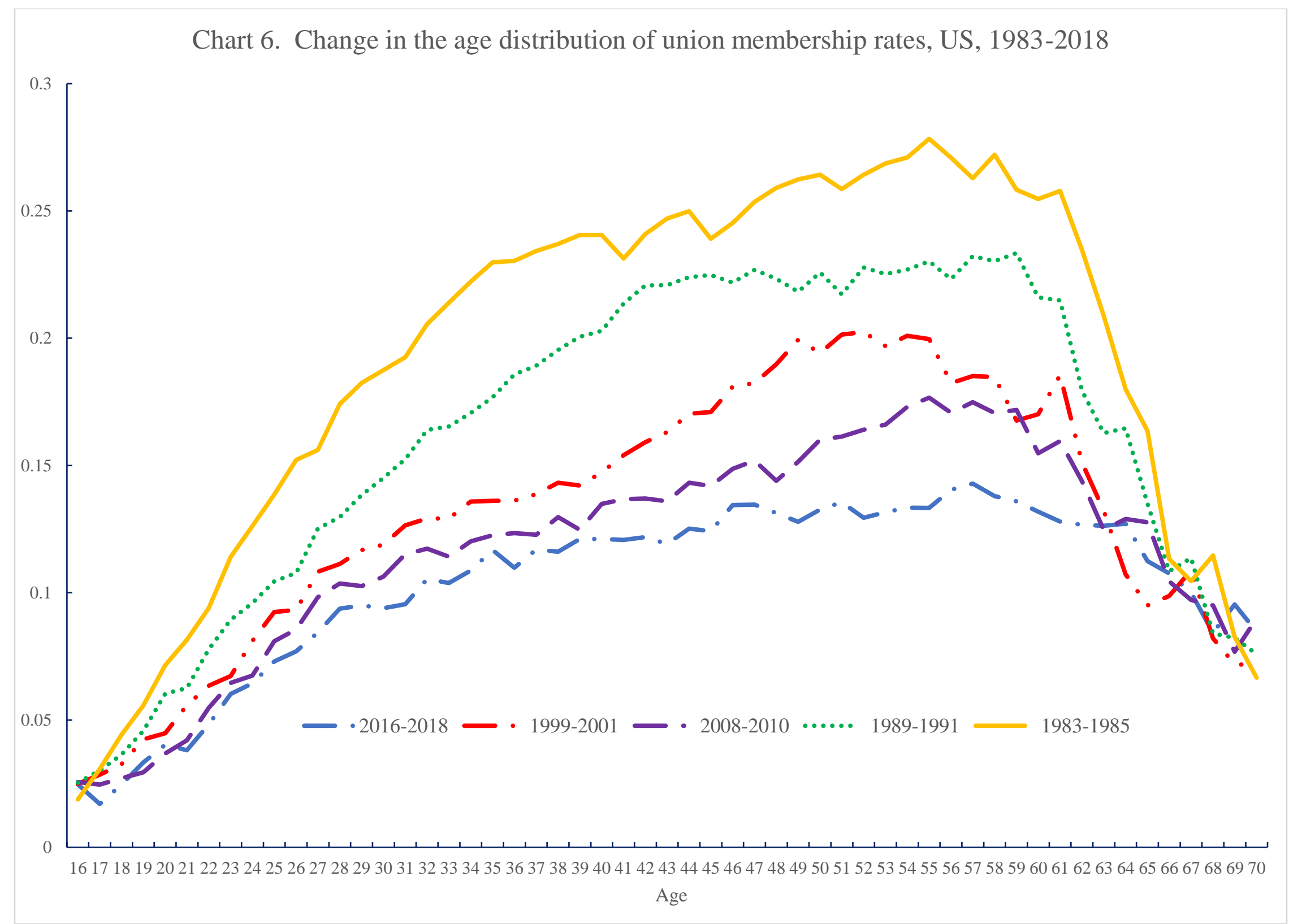




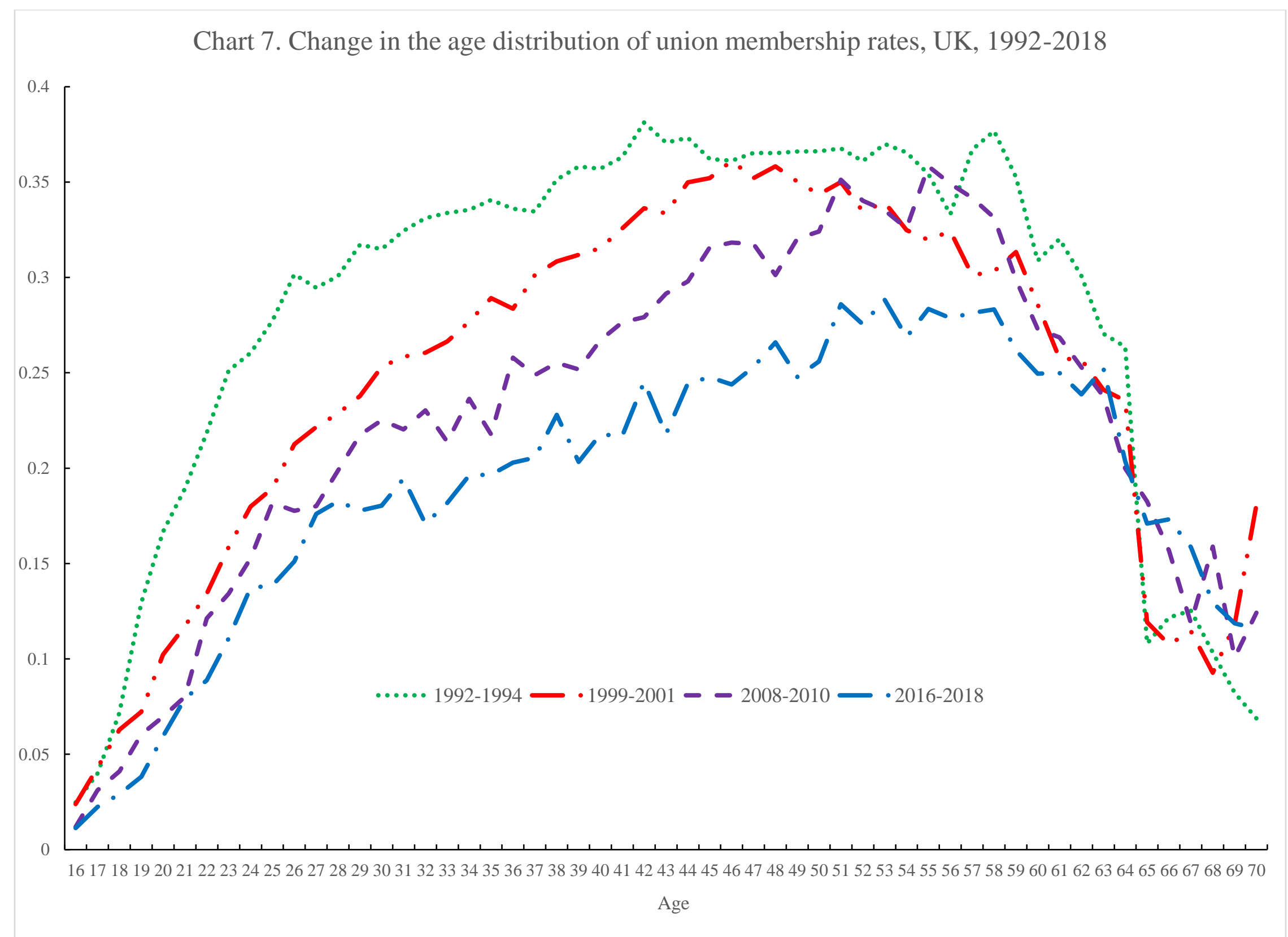




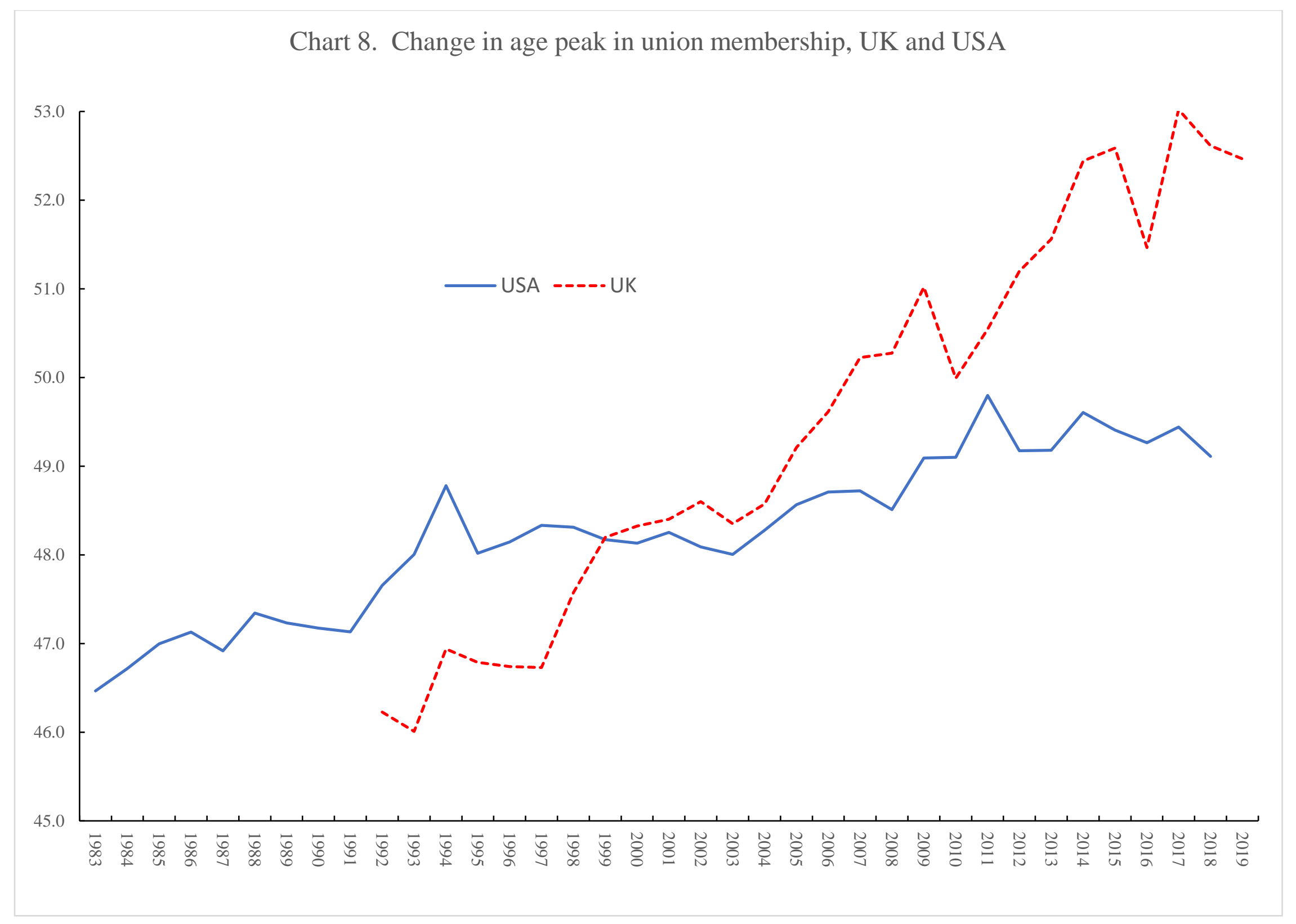




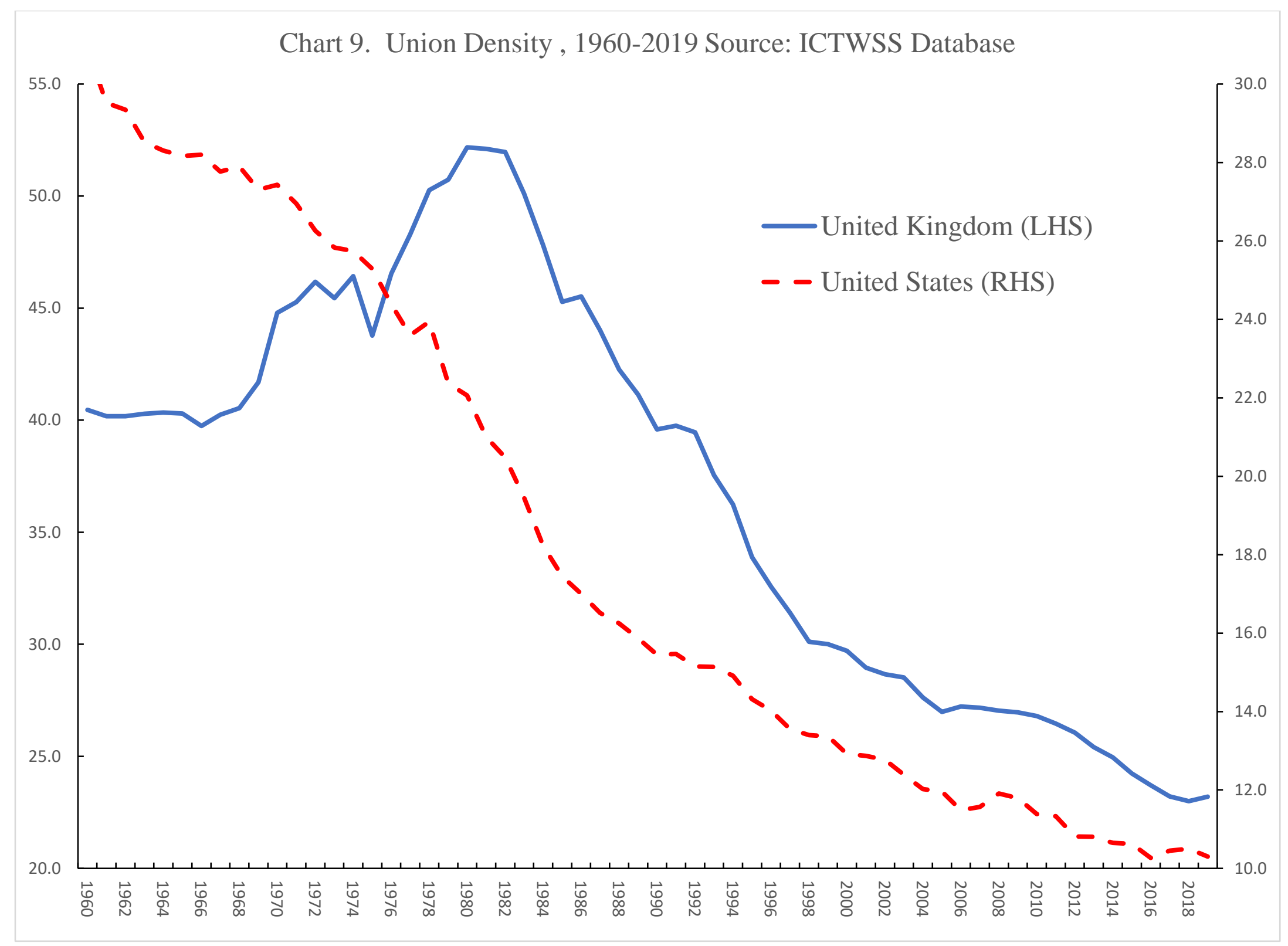

